Chapter 5

\title{
Mass Production of Mesenchymal Stem Cells - Impact of Bioreactor Design and Flow Conditions on Proliferation and Differentiation
}

\author{
Valentin Jossen, Ralf Pörtner, Stephan C. Kaiser, \\ Matthias Kraume, Dieter Eibl and Regine Eibl \\ Additional information is available at the end of the chapter \\ http://dx.doi.org/10.5772/59385
}

\section{Introduction}

Stem cells have enormous potential in health and medical research due to their ability to differentiate into specialized cells and to self-renew. Applications can be seen in cell-based therapies, e.g. for the treatment of Parkinson's disease, type I diabetes, arthritis, burn victims, and cardiovascular diseases, as well as in tissue engineering of artificial organs, development and testing of drugs, and in vitro toxicity tests [1-9].

In general, stem cells are cells generating identical daughter and progenitor cells, which both have the ability to develop terminally differentiated functional cells after going through a defined differentiation process $[10,11]$. There are two types of stem cells, varying in their ability to differentiate, methods of isolation and propagation and, thus, their application potential: embryonic stem cells and adult stem cells. Whereas embryonic stem cells represent pluripotent cells which are able to grow into all derivatives of the three germ layers, adult stem cells are only able to develop into a limited number of cells. Adult stem cells, to which mesenchymal stem cells (also referred to as mesenchymal stromal cells) belong, are of postnatal origin, are more tissue-specific, and regarded as multipotent. In this work the focus is laid on mesenchymal stem cells (MSCs) as they have become increasingly important in the field of regenerative medicine in recent years. Numerous clinical studies have confirmed the safety of allogenic and autologous MSCs for treatment of human diseases [12,13]. Currently, MSCs are being investigated in terms of their therapeutic potential for inflammatory, autoimmune and degenerative conditions in preclinical and clinical studies $[14,15]$. 
Between the late 1960s and the 1980s, Friedenstein et al. [16-18] and Owen et al. [19,20] described tissue-specific progenitor cells capable of differentiation to cells of mature tissues. They worked with subpopulations of bone marrow cells characterized by osteogenic potential. Interestingly, the term MSC was introduced in 1991 for the first time. Caplan [21] proposed classifying adult stem cells as MSCs, if they were able to differentiate to all cells of mesodermal lineage, although their multilineage potential was only demonstrated later by Pittinger et al. [22] (for review see [23]). Between the 1990s and 2000s numerous studies were conducted with cell populations that were, strictly speaking, not MSCs according to Caplan's proposed definition. Finally, as it became impossible to compare results, a revision of the MSC definition was introduced by the International Society for Cellular Therapy (ISCT) in 2006 [24]. The ISCT definition is based on two cellular properties of MSCs which are morphologically similar to fibroblasts: (1) their adherence to plastic and (2) their trilineage differentiation to adipogenic, chondrogenic and osteogenic cells [25]. Additional requirements include positive expression of CD105 (endoglin marker), CD73 (ecto-5'-nucleotidase marker) and CD90 (Thy1 marker), and negative expression of CD45 (leukocyte marker), CD34 (hematopoietic stem cell marker), CD14 or CD11b (monocyte and macrophage markers), CD79 or CD19 (B cell marker), and human leukocyte antigen class II.

As things stand, bone marrow aspirate represents the most often used source [22] of MSCs. In addition, MSCs are obtained from adipose tissue [26], placenta as well as umbilical tissue [15] and blood [27,28], and peripheral blood [29] (Figure 1). Other sources, such as periosteum, trabecular bone, synovia, skeletal muscle, deciduous teeth, fetal pancreas, lung, liver and amniotic fluid, have also been reported [15]. But independent of the source, the low frequency of MSCs makes their direct collection for the majority of MSC applications unfeasible. A therapeutic dose has been reported to range between 1 and $1000 \cdot 10^{6}$ cells per $\mathrm{kg}$ body weight [30-33], whereby the exact dosage is determined by the type of disorder. However, when expanding MSCs for particular therapies, the type of therapy (that is, either an allogeneic or autologous one) also needs to be taken into account. In doing so, the ability of MSCs (which display heterogeneous cell populations that vary from donor to donor and depend on donor age and tissue) $[34,35]$ to rapidly proliferate in vitro is exploited.

In order to fulfill the potential of MSCs as therapeutic agents for a wide range of applications, culture conditions need to be optimized to obtain clinical grade MSCs with defined safety standards at large scale $[14,15,31,41-46]$. To achieve this, strategies for preparation of the required quantities of cells, have to be implemented, which allow the undifferentiated state to be preserved or direct stem cell differentiation into the desired lineage. Scalable culture systems with optimized culture strategies and controlled culture environment are prerequisites for the successful transfer of stem cell-based therapy concepts into clinical routine. In the following, we describe the main characteristics of MSCs with respect to cultivation, appropriate cultivation methods for mass production, and a new scale-up-approach for expanding human mesenchymal stem cells (hMSCs) derived from adipose tissue (hADSCs) and bone marrow (hBM-MSCs). 


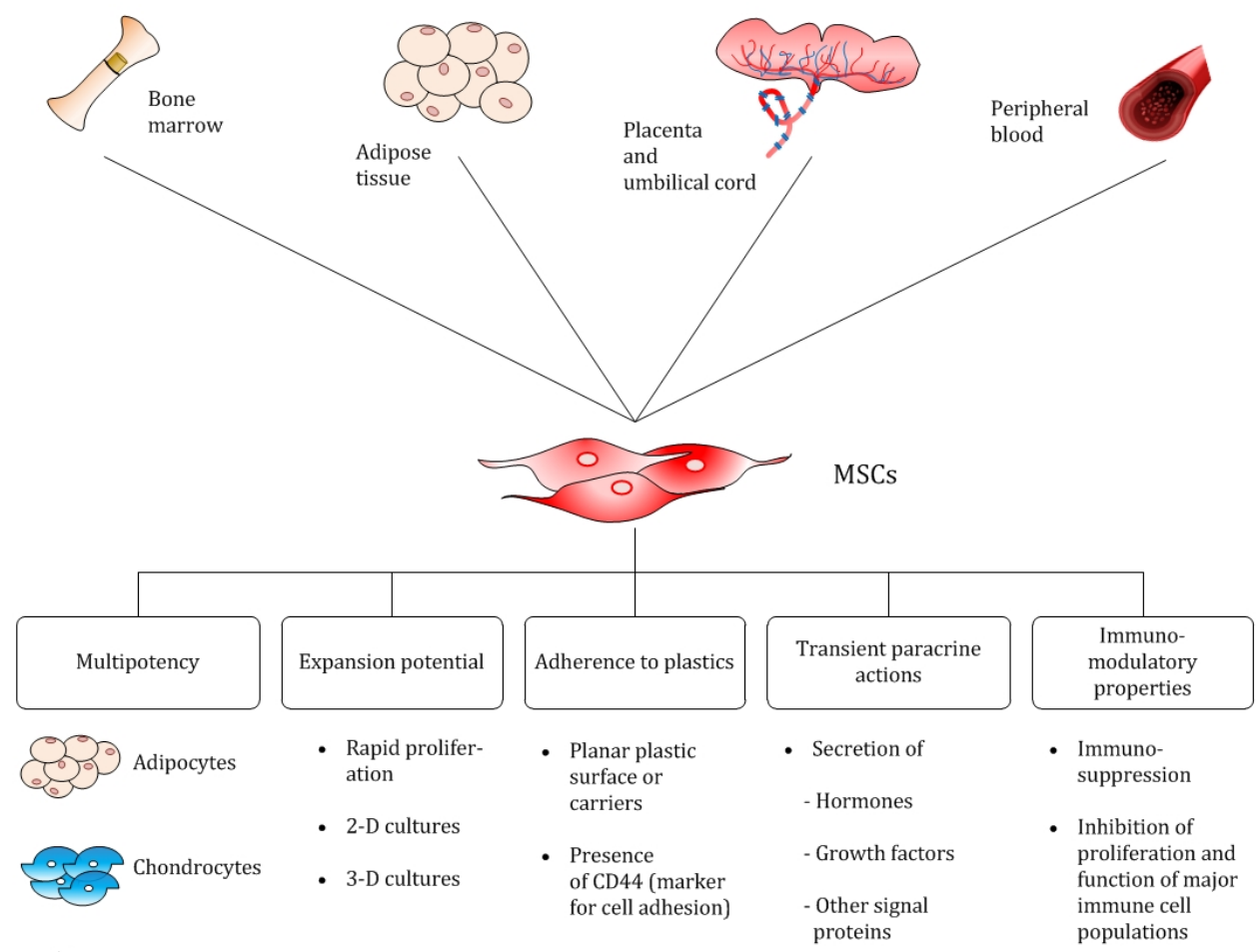

Osteocytes

Figure 1. Main sources and properties of MSCs. Today`s high pre-and clinical interest in MSCs is ascribed not only to their multipotency, but also to their paracrine secretion of angiogenic factors, cytokines and immunomodulatory substances, which is documented by a body of literature (e.g. [36-40]).

\section{Characteristics of MSCs and the influence of the engineering parameters on the cultivation}

\subsection{Main factors influencing MSC cultivation}

For the successful expansion of stem cells appropriate culture conditions are essential. When working with MSCs in vitro, the problems are non-infinite growth and non-complete directed differentiation [47]. A critical step is the isolation of specific stem cells, as they often occur in small quantities and only in a tissue formed by other cells. Therefore, special protocols for their isolation and preservation are required [48]. Furthermore, in vivo stem cells live in a highly specialized microenvironment. This microenvironment interacts with a number of characteristics such as the extracellular matrix surrounding the cells and mediators on growth and differentiation. These factors have to be modeled for in vitro expansion by appropriate selection 
of the matrix for cell adhesion, the culture medium including growth factors, and the physical environment, i.e. temperature, $\mathrm{pH}$, oxygen and shear effects.

Self-renewal and the differentiation potential of stem cells are influenced to a large extent by donor age and passage number $[49,50]$. In general, MSCs can be expanded by several orders of magnitude in a few weeks [51] due to their high expansion potential. But with increasing passage number they can lose their multipotency or their specific cell surface markers might be downregulated, resulting in a loss of the therapeutic properties of these cells [52]. After 30 to 40 doublings MSCs become senescent, accompanied by inhibited growth and induction of apoptosis [53]. It is assumed that this effect is induced to some extent by the harsh enzymatic treatment during subcultivation, e.g. by trypsinization. Consequently, techniques without subcultivation have been investigated to prolong the proliferation phase and to increase the expansion factor [54]. Kretlow et al. [50] observed that both increasing age and the number of passages have lineage dependent effects on MSC differentiation potential. In addition, there seemed to be an interplay between donor age and cell passage number. These effects are of high relevance for clinical therapies, because they might have strong impact on the cultivation protocol.

As mentioned above, the extracellular microenvironment plays a significant role in controlling cellular behavior. In recent years, different biomaterials have been studied to find a microenvironment that is conducive to stem cell growth and differentiation, and that mimics the in vivo situation, at least to some extent (reviewed by [55]). Appropriate biomaterials can support the cellular attachment, proliferation, and lineage-specific differentiation of stem cells. In the case of MSC differentiation growth factors or factors known to induce lineage commitment of stem cells were incorporated into cultures with scaffolding materials, quite often for regulation of osteogenic, chondrogenic or adipogenic differentiation [56-59]. Because such scaffolding materials are not normally used for MSC expansion, they are not further discussed here.

For expansion with the final goal of harvesting large quantities of MSCs, they are typically adhered to a surface with optimized surface chemistry and topography, which supports cell attachment, spreading and proliferation (Figure 2). Today, routine cultivation of MSCs is performed in planar plastic plates and flasks ensuring two-dimensional (2-D) growth [60]. Reusable glass systems are very seldom utilized at this time. As plates and flasks allow for a limited expansion only and subcultivations exceeding 6 passages (see above) should be avoided (high risk of cell differentiation), scalable matrices have been established. These matrices cover hollow fiber membranes, macrocarriers [61,62] and, in particular, microcarriers (see also Section 3).

Microcarriers are small spherical particles differing in core material, density, diameter and surface charge, and are intended for use in suspension bioreactors. Table 1 gives an overview of commercially available microcarriers that are suitable in MSC expansions. Depending on the porosity, the microcarriers are classified into non-porous, micro-porous (pore sizes $<1 \mu \mathrm{m}$ ) and macro-porous types (pore sizes between 10 and $50 \mu \mathrm{m}$ ). Whereas in non-and microporous microcarrier cultures the cells attach to the surface of the beads, in macro-porous microcarrier cultures they grow in the pores. However, cell harvest is more complicated, which is a general challenge in microcarrier-based cultivations. While taking care to avoid differentiation or even 


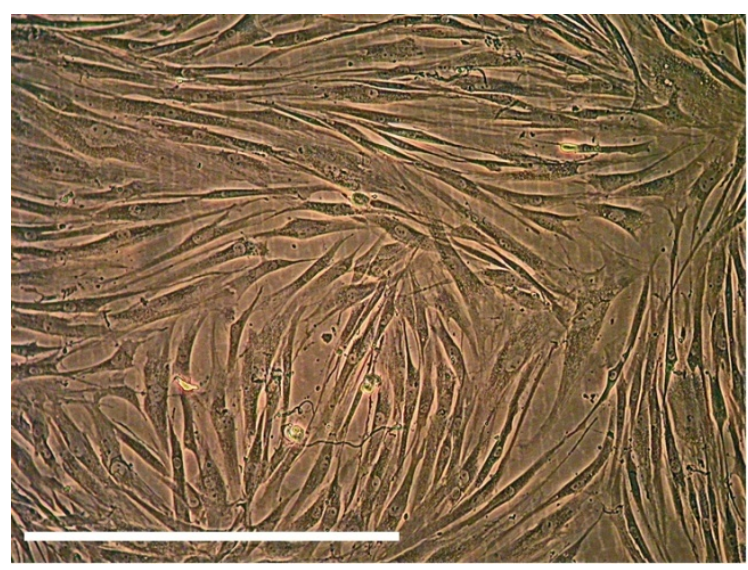

Figure 2. Adherent glandular stem cells grown in a T-Flask (bar: $500 \mu \mathrm{m}$ ).

damage, the cells are normally harvested after chemical treatment [63-65]. Examples of stem cell proliferation on microcarriers can be found in [66-69].

\begin{tabular}{llllll}
\hline \multicolumn{1}{c}{ Type } & \multicolumn{1}{c}{$\begin{array}{c}\text { Diameter } \\
{[\mu \mathrm{m}]}\end{array}$} & $\begin{array}{c}\text { Density } \\
{\left[\mathbf{k g} \cdot \mathbf{m}^{3}\right]}\end{array}$ & $\begin{array}{c}\text { Surface area } \\
{\left[\mathrm{cm}^{2} \cdot \mathbf{g}^{-1}\right]}\end{array}$ & $\begin{array}{c}\text { Charge } \\
{[+/-]}\end{array}$ & Core material \\
\hline CultiSpher-G & $130-380$ & 1020 & - & none & Gelatin \\
\hline CultiSpher-S & $130-380$ & 1020 & - & Gelatin \\
\hline Cytodex I & $147-248$ & 1030 & 4400 & + & Cross-linked dextran \\
\hline Cytodex III & $141-211$ & 1040 & 2700 & none & Cross-linked dextran \\
\hline Collagen & $90-150 / 125-212$ & 1020 & $480 / 360$ & none & Cross-linked polystyrene \\
\hline FACT III & $90-150 / 125-212$ & $1020 / 1040$ & $480 / 360$ & + & Cross-linked polystyrene \\
\hline Hillex II & $160-180$ & 1110 & 515 & + & Modified polystyrene \\
\hline Hillex-CT & $160-180$ & 1110 & 515 & + & Modified polystyrene \\
\hline Plastic & $90-150 / 125-212$ & $1020 / 1040$ & $480 / 360$ & none & Cross-linked polystyrene \\
\hline Plastic Plus & $90-150 / 125-212$ & $1020 / 1040$ & $480 / 360$ & + & Cross-linked polystyrene \\
\hline ProNectin F & $90-150 / 125-212$ & $1020 / 1040$ & $480 / 360$ & none & Cross-linked polystyrene \\
\hline Glass & $90-150 / 125-212$ & $1020 / 1040$ & $480 / 360$ & none & Cross-linked polystyrene \\
\hline
\end{tabular}

Table 1. Overview of commercially available microcarriers for the cultivation of MSCs. Non-porous microcarriers=Hillex II, Hillex-CT, Plastic, Plastic Plus, ProNectin F, Glass; micro-porous microcarriers=Cytodex I, Cytodex III; macro-porous microcarriers=CultiSpher-G, CultiSpher-S. 
An alternative is carrier-free cultivation in 3-D (three-dimensional) aggregates or spheroids, or encapsulation, e.g., in alginate [70] or in hydrogels [57,71-79]. These techniques are often used to induce a lineage specific differentiation. With respect to the expansion of MSCs, there is conflicting evidence in the literature with regard to the usefulness of these techniques. Detrimental effects such as altered proliferation, stem cell marker expression, cell shape and modified differentiation potential have been reported [80,81]. A general problem in 3-D aggregates can be seen in the inhomogeneous supply of oxygen and nutrients. Therefore, it is unlikely that carrier-free cultivation of MSCs is an appropriate approach for the standardized production of large quantities of cells with consistent product quality.

A further strong impact on MSC proliferation and differentiation is exerted by the culture medium through its composition (content of nutrients such as glucose or glutamine, growth factors, type and concentration of serum), culture conditions such as $\mathrm{pH}$ or oxygen concentration, and the density, in which the cells were plated/seeded [47].

Due to the importance of hyperglycemia in vivo and the hypothesis, that high glucose could be deleterious to stem cell therapy, the impact of glucose on proliferation, potential for differentiation, and other physiological effects have been studied intensively. Glucose concentration in basal media has been shown to have both positive and negative impacts on MSC growth [47,82-93]. It is beyond the scope of this chapter to discuss the various effects in detail but certain findings are presented below to highlight the complexity of this topic:

- Evidence of retention of MSC characteristics from different sources with regard to surface marker profiling, proliferation, differentiation and karyotyping when cultured extensively in DMEM-HG medium containing a high glucose concentration of $25 \mathrm{mM}$ [83].

- Increase in peak cell density by $40 \%$ at low glucose concentration ( $5.5 \mathrm{mM})$ when compared with an expansion at high glucose concentration (25 $\mathrm{mM})$ [84].

- High glucose concentration in cell culture medium did not acutely affect hMSC growth factor or proliferation [88].

- High glucose $(25 \mathrm{mM})$ enhanced telomerase-immortalized human mesenchymal stem cell (hMSC-TERT) proliferation in long-term studies in contrast to hMSCs, where proliferation was unchanged. Thioredoxin-interacting protein, which is involved in apoptosis regulation, was stimulated by glucose in hMSC-TERT. However, in both cell types apoptosis was not influenced by high glucose levels [90].

- Culture in high glucose-containing medium had a negative effect on colony formation and differentiation for rat non-adherent bone marrow MSCs [91].

- Glucose reduction prevents replicative senescence and increases mitochondrial respiration in hMSCs [94].

- High glucose conditions suppress the function of bone marrow-derived endothelial progenitor cells via inhibition of the eNOS-caveolin-1 complex [82].

- High glucose regulates cyclin D1/E of hMSCs through TGF-beta1 expression via Ca2 /PKC/ MAPKs and PI3K/Akt/mTOR signal pathways [92]. 
It seems that MSCs are affected by high glucose concentrations. However, in respect of proliferation and differentiation, no real advantage of low glucose concentrations has been found to date. Our own data (not published) indicate that the effect of high glucose concentrations on MSC-fate depends to a large extent on the medium formulation, e.g. the type and concentration of serum or growth factor concentration (see also below). For practical reasons, cultivation at high glucose levels has some advantages, as in low glucose media more frequent medium-feeding or exchange is required than at higher cell densities.

The impact of glutamine has been studied less extensively than that of glucose. Ferrari et al. observed an increase in peak cell density by approx $25 \%$ when adding of 2 to $6 \mathrm{mM}$ of glutamine [84]. Schop et al. concluded from their studies that glutamine has no importance as an energy source for hMSCs [93].

In the cultivation and differentiation of stem cells, growth factors play an important role. They influence self-renewal, senescence, aging, embryonic development and differentiation [95]. Thus, they create an appropriate microenvironment and provide important messenger signals for cells. In effect, growth factors can induce or inhibit signaling cascades in the cells via receptors on the cell surface which affect cell physiology [96]. In many types of stem cells, regulation of self-renewal is done by proteins of the fibroblast growth factor (FGF)-family [95]. For example, for FGF-2 an improved expansion was demonstrated [97]. The absence of aforementioned growth factors may lead to differentiation of stem cells, which is unwanted in the pure propagation of the cells [98]. Again, the appropriate concentration of growth factors needs to be determined depending on the cells, medium composition etc. [99].

A further important medium compound with respect to stem cell physiology is serum, in particular its type and concentration. At present, most studies are performed using fetal calf serum (FCS) or fetal bovine serum (FBS) in concentrations between $10 \%$ and $20 \%$ [100]. In Section 5 an example with reduced FBS concentration is discussed. Clinical studies require a GMP-compliant medium $[43,101]$ due to the drawbacks of serum (non-human origin, possible contamination etc.) [102]. Although human serum has positive effects compared to FCS or FBS, extended use for large scale processes is doubtful due to limited availability. Replacement of serum containing medium by serum-free medium formulation has been addressed by a number of publications during the last few years [103-113]. The first serum-free culture media (for example StemPro ${ }^{\circledR}$ MSC SFM XF) for MSCs are now commercially available. However, the cultivation results (cell yields) have not proved satisfactory and the matrix is generally being pre-coated with serum [114,115].

Hypoxic conditions are regarded as advantageous for stem cell proliferation and differentiation. MSCs grown in vitro with reduced oxygen content in the gassing air were characterized by increased cell proliferation. It has been shown that at $1 \%$ and $5 \%$ oxygen in the gassing air the cells enter the exponential growth phase earlier and produce less inhibitor substances $[114,116]$. Our own studies (data not published) underline this, but indicate that with an optimized medium the positive effect of low oxygen concentration seems to be smaller. Further culture parameters such as osmolality, $\mathrm{pH}$ and temperature might influence stem cell fate, but these parameters have not yet been studied intensively so far. 
For large scale expansion of MSCs, the cell density required for seeding has a strong impact on the expansion capacity. Due to restricted availability of the cell material and limited population doubling or passage number, the lowest possible seeding density of cells should be applied [51,117]. Fortunately, the literature data suggest that seeding MSCs at low densities ( 2.5 instead of 2500 cells cm$^{-2}$ ) can increase cell proliferation and cell density while maintaining marker profile [118]. Colter et al. seeded 1.5 and 3.0 cells cm$^{-2}$ and successfully generated single cell-derived colonies [51]. Hewitt et al. [119] found the best conditions for cell expansion on microcarriers to be 3000 microcarriers $\mathrm{mL}^{-1}$ (ca. $1 \mathrm{~g}$ dry weight $\mathrm{L}^{-1}$ ) in flasks. They determined a seeding density of 5 cells per microcarrier. Higher growth rates of MSCs seeded at lower densities are explained by a longer exponential growth phase, more population doublings, and more availability of nutrients per cell [120].

\subsection{Shear stress and the influence of engineering parameters on MSC proliferation and differentiation}

\subsubsection{General basics}

There is strong evidence that growth and differentiation of stem cells are effected by several types of mechanical forces including stretch, strain, compression, and shear stress [121]. Due to the importance of shear stress, the fundamentals are given in this section before shear effects on expansion of MSCs are discussed.

Cells growing adherent to a solid matrix are exposed to shear forces from the moving fluid. By definition shear in a fluid system has two components, shear stress $\tau$ and shear rate $\gamma$. Shear stress is a force per unit area acting on and parallel to a surface. Shear rate is a measure of a velocity gradient (velocity/length). The two quantities are therefore related in laminar Newtonian fluid - and cell culture media are regarded as Newtonian - by

$$
\tau=\eta_{f l} \cdot \gamma
$$

where $\eta_{f l}$ is the viscosity of the fluid. In model systems such as laminar flow between two parallel plates, cone-and-plate viscometer or a coaxial cylinder Searle viscometer, the shear rate and corresponding shear stress can be calculated by simple mathematical equations. Shear effects are often investigated in flow chamber bioreactors consisting of parallel plates [122]. In this apparatus, a laminar flow causes a defined wall shear stress $\tau_{w}$ on the bottom plate where the cells grow adherently (see Figure 3). The shear stress for a Newtonian fluid at a surface element parallel to a flat plate at the point $\mathrm{y}$ is given by

$$
\tau=\eta_{f l} \cdot\left(\frac{d U}{d y}\right)
$$

where $U$ is the velocity of the fluid along the boundary and $y$ is the height above the boundary. Specifically, wall shear stress is defined as: 


$$
\tau_{w}=\eta_{f l} \cdot\left(\frac{d U}{d y}\right) \quad \mathrm{y}=0
$$

Flow velocity $U(y)$ can be calculated for given values of the flow rate $F$, the height $h$ and the width $b$ of the flow chamber (Figure 3):

$$
U(y)=\frac{6 F}{b \cdot h^{3}} \cdot\left(h \cdot y-y^{2}\right)
$$

Wall shear stress $\tau_{w}$ acting on the cells is given by:

$$
\tau_{w}=\eta_{f l} \cdot\left(\frac{d U}{d y}\right) \quad \mathrm{y}=0=\frac{6 F \eta_{f l}}{b h^{2}}
$$

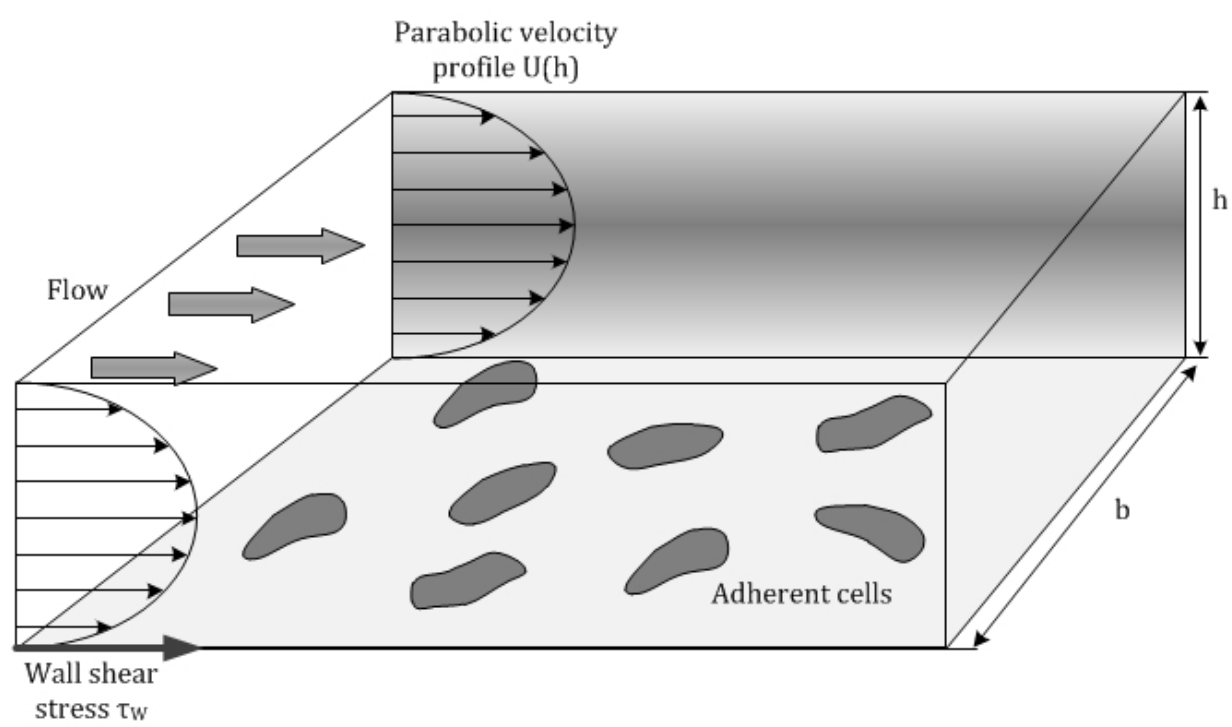

Figure 3. Wall shear stress acting on adherent cells in a flow chamber with parallel plates. For abbreviations see text (modified from [122], with kind permission from Springer Science and Business Media).

In the complex, mostly turbulent environment in a culture system (bioreactor), the local shear rate varies within the vessel and it therefore is more difficult to associate cellular effects (cell damage, differentiation etc.) with the magnitude of the prevailing shear rate or the associated shear stress. An example is given in Figure 4 for cells grown on microcarriers in suspension, e.g. a spinner flask, a stirred bioreactor or a wave-mixed bioreactor (see Section 3). 


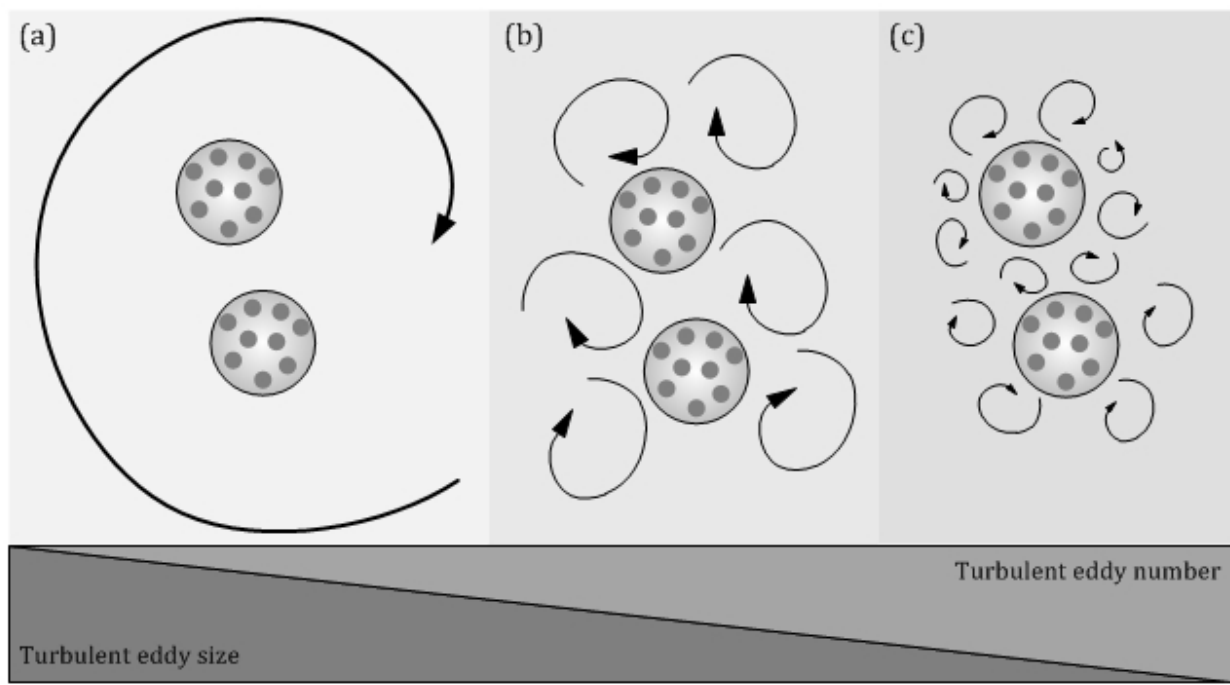

Microcarrier with adherent cells

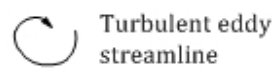

Figure 4. Shear forces on microcarriers in a turbulent flow. Microcarrier-eddy interactions: (a) eddies much larger than beads, (b) multiple eddies the same size as beads, (c) eddies the size same as interbead spacing.

Several concepts to describe the complex shear effects on cells in a turbulent flow were described and evaluated with available data in respect of the impact of shear forces on microcarrier cultures in bioreactor systems (reviewed in [122]). Among others, the concept of an "Integrated Shear Factor" ISF - a measure of the strength of the shear field between the impeller and the spinner flask walls - was developed to describe shear damage to continuous mammalian cell lines [124]. For a stirred bioreactor, the ISF is given by

$$
I S F=\frac{2 \pi n_{R} d_{R}}{D_{R}-d_{R}}
$$

with rotational speed $n_{R}$, vessel diameter $D_{R}$ and impeller diameter $d_{R}$. According to Cherry und Papoutsakis [123] the largest shear stress to which cells grown on microcarriers are exposed occurs in turbulent eddies which are the same size as the microcarriers. The energy of the eddies is transferred to the surface of the microcarriers, resulting in high local velocity gradients between the microcarriers and the fluid, and the highest shear rates on the cells. The microcarriers are caused to rotate within these eddies. Using Kolmogorov's theory the length scale $1_{\text {Kol }}$ of the smallest eddies are in the order of 


$$
l_{K o l}=\left(\frac{v^{3}}{\varepsilon}\right)^{1 / 4}
$$

where $v$ is the kinematic viscosity and $\varepsilon$ the energy dissipation rate per unit mass

$$
\varepsilon=\frac{P}{\rho_{f l} V_{L}}
$$

with power input $\mathrm{P}$ and liquid volume $\mathrm{V}_{\mathrm{L}}$. The Kolmogorov eddy length scale corresponds to the diameter of the smallest eddy generated in the bioreactor. In a turbulent environment, eddies break down to form smaller eddies. On the Kolmogorov length scale, viscosity dominates and the turbulent kinetic energy is dissipated into heat. When the Kolmogorov eddy length scale becomes equivalent to the diameter of the microcarrier, movement of the flow lines can shear the cells. The Kolmogorov eddy length scale is affected by stirrer speed, liquid properties and impeller design. Croughan et al. [125] used this concept to describe cell damage in respect of cells grown on microcarriers. Damage became significant when the microscale was about two-thirds the size of the microcarriers, or smaller (discussed by [119]).

Besides the above-mentioned concept for estimation of shear stress in bioreactors, several numbers are used to characterize culture systems (bioreactors) such as (1) geometric dimensions, (2) volumetric power input $(\mathrm{P} / \mathrm{V}),(3)$ power number (Newton number, $\mathrm{Ne}$ ), which is defined as

$$
N e=\frac{P}{n_{R}^{3} d_{R}^{5} \rho_{f l}}
$$

for stirred bioreactors (with rotational speed $\mathrm{n}_{\mathrm{R}}$ and fluid density $\rho$ ), (4) volumetric mass transfer coefficient $\left(\mathrm{k}_{\mathrm{L}} \mathrm{a}\right)$ for oxygen or $\mathrm{CO}_{2}$, (5) mixing time, (6) Reynolds number, which is given by

$$
\operatorname{Re}=\frac{\rho_{f l} n_{R} d_{R}^{2}}{\eta_{f l}}
$$

for stirred bioreactors, $(7)$ impeller tip speed $\left(\mathrm{u}_{\mathrm{tip}}\right)$ for stirred bioreactors, and $(8)$ volumetric gas flow, among others. These numbers can be used to compare process parameters in different bioreactor systems. Recommendations for determination of these parameters have been published by [126] and [127], for example.

The numbers introduced above are not usually suitable for a more in-depth description of fluid flow in a bioreactor. This can be accomplished by computational fluid dynamic (CFD) 
simulations [128-130]. CFD uses numerical methods and algorithms to solve and analyze problems that involve fluid flows. This is especially important for tissue engineering constructs, in which a set of complex phenomena such as hydrodynamics, nutrient transfer, cell growth, and matrix deposition have to be taken into account [131-133]. Parameters such as fluid velocity, oxygen tension, stress, and strain, which are difficult to determine experimentally, can be derived from CFD simulations and related to cellular parameters [132]. This is advantageous for complex culture systems, where it is impractical or almost impossible to install probes to determine fluid specific parameters (see Section 5).

\subsubsection{Shear stress in MSC cultivations}

Flow-induced shear stress can be stimulating or detrimental to the behavior of MSCs. In the following, firstly a brief review of basic studies is given. These studies were mostly intended to induce a lineage-specific differentiation of stem cells in which the main goal is to engineer a microenvironment for controlled stem cell differentiation [134-136]. Secondly, the impact of shear on stem cells grown in bioreactors for mass cell production is discussed.

\subsubsection{Effects of shear stress on stem cell fate}

Shear stress can affect stem cells in different ways [137,138], e.g. with respect to morphology, proliferation capacity, gene expression, cell cycle arrest and apopotosis, proteomic profiling, and differentiation [139-147]. In some cases opposing conclusions have been reported. Adamo and Garcia-Cardena [139] as well as Chang and Wang [140] observed changes in the cell morphology of MSCs due to shear stress (e.g., differences in morphology between static and dynamic culture systems). Changes in morphology can have an influence on cell proliferation potential, as shown in earlier studies by Prockop and coworkers [142]. They reported that smaller agranular cells divided faster than large granular cells, while the doubling time and the differentiation potential remained the same. These results are contrary to those of Luo et al. [143] and Maul et al. [144], who found that shear stress does not support cell proliferation, but leads to cell cycle arrest or a decrease in cell number.

Numerous reports have addressed the induced differentiation of MSCs by shear stress [137], mostly osteogenic $[138,148-154]$ and chondrogenic $[155,156]$. Meanwhile, a suitable bandwidth for shear effects on MSCs has been determined. In general, increasing shear stress seems to promote osteogenesis and mineralization [137], but some of the findings are again contradictory. This is explainable to some extent through the different cultivation systems or bioreactors used. Studies on the effect of shear forces were performed in either 2-D cultures (flow chambers) with defined shear stress or in perfused macroporous carriers [157]. While in twodimensional flow chambers (cell growth as monolayer) shear stress levels of 0.5-2 Pa are required for stimulation of osteoblasts [151], which is in the order of the postulated Weinstein shear forces of 0.8-3 Pa in the Haversian channels [158], the results are not readily transferable to 3-D systems. 3-D bioreactors with perfusion or rotational motion (see Section 3) also show the influence of flow on the osteogenic differentiation of osteoblastic cell lines, primary osteoblasts and osteoblast precursor cells [159-163]. However, the calculated shear stresses were in part up to 2-5 orders of magnitude below the values of the 2-D flow chambers. For 
greater understanding of effects in scaffolds, computer-based simulations are increasingly used to detect the magnitude of shear forces [164,165]. The shear stress acting in the scaffolds is usually in the range of a few $\mathrm{mPa}$. However, this is often not caused by the local shear forces acting on the cells, which are ultimately the important ones, but by those in the bulk flow. Furthermore, it is rarely taken into account that in the various perfusion bioreactors not only the perfusion rate for the development of local flow and shear forces is important, but also matrix properties such as porosity, pore size, interconnectivity of the pores, and elasticity and extensibility of the relevant material $[162,166,167]$. Moreover, with respect to tissue engineering, fluid dynamic calculations are rarely coupled with mass transfer effects. In principle, it cannot therefore be excluded that the effects observed are not due to a mechano-stimulation of the cells, but to improved mass transport. Furthermore, different culture conditions such as medium composition, type of serum, oxygen concentration etc. might also play a role (see above).

\subsubsection{Effect of shear stress on stem cells grown in bioreactors for cell expansion}

For high level expansion of stem cells, bioreactor cultivations are required that support the required number of cells. This involves minimal variations in lineage specific differentiation while the genetic and epigenetic stability of the cells needs to be kept under control [132]. In order to ensure this, the environment acting on the cells in a bioreactor needs to be characterized and kept similar during upscaling of the process. To date, microcarrier-based suspension cultures have been studied mostly for expansion of stem cells (see above) as they provide a sufficient surface area for attachment and expansion $[119,168]$. Microcarriers are preferably suspended in stirred bioreactors (see Section 3.2), where shear-influenced stem cell differentiation and shear-induced cell damage can be distinguished. The damaging effects of flow stress in microcarrier cultures were studied in the 1980s and 1990s mostly in relation to permanent or established cell lines [124]. Recent publications show that stem cells are affected by shear stress below damaging levels (reviewed by [132]). With respect to cell expansion, preferably without significant unwanted differentiation, a narrow band of shear stress levels is essential [169]. Turbulent flow in stirred bioreactors, however, represents a scenario that is not characterized by a narrow band of shear stress levels. The effect of broadband stresses associated with turbulence in stirred bioreactors on preservation of the differentiation potential of stem cells and minimization of lineage commitments is still poorly understood $[119,132,170-172]$. Furthermore, controversial observations on the shear stress tolerance of the cells might be due to protective substances contained in the medium, such as serum or differences in the type of surface or cell density. Thus, for example, cells grown in the pores of macroporous carriers are better protected against shear than cells grown on non-porous carriers $[63,67,173]$.

To summarize, on the one hand shear stress can be deliberately used for targeted differentiation of stem cells. On the other hand, with respect to stem cell expansion, shear effects need to be minimized to prevent an unwanted differentiation. Therefore, in order to optimize process design, the specific task of the cultivation or the target product should always be kept in mind. During production of cell therapy products, cell expansion and harvest are in the foreground, 
and cell differentiation is generally undesirable. In the discussion that follows, the focus is placed on epansion of MSCs and suitable bioreactors for cell therapy. Based on a classification of the power input type and operating principles, the most common bioreactors are presented and cultivation results are discussed.

\section{Bioreactor systems for cell therapeutics}

\subsection{Classification}

Since the early 2000s successful MSC expansions have been reported. In addition to static bioreactors (Figure $5 \mathrm{~A}$ ), different types of dynamic bioreactor versions (Figure $5 \mathrm{~B}$ ) have proven themselves. 2-D cultivations performed in planar systems such as petri dishes, T-flasks, and stacked plate systems are still predominant in both the development and production of cell therapeutics. Stacked plate systems (e.g., CellSTACKs ${ }^{\circledR}$, CellFactories) with 10-or 4-layer vessels are typically made of polystyrene and are non-instrumented, and have become the system of choice in semi-commercial and commercial production processes [31,174]. Their mass and energy transfer is exclusively caused by conduction and reaction processes within the planar system and by interaction with an environment that is typically temperature and humidity controlled. In other words, gas exchange only takes place at liquid-gas interphase and concentration gradients can appear during cultivations. Not surprisingly, culture broth inhomogeneities, which influence cell yield and quality, increase as the number of layers in the vessel rises. Moreover, manipulations become more complicated and risk of contamination also increases. In spite of additional attempts to apply robotics and bioreactor control to static bioreactors [175,176], dynamic bioreactors ensuring 2-D or 3-D cell growth remain superior.

In dynamic bioreactors the power input generated is responsible for mass and energy transfer. To date, a high number of different dynamic bioreactors have been used to expand MSCs. According to the type of power input, they can be divided into mechanically driven, pneumatically (air-) driven and hydraulically driven systems. Mechanically driven bioreactors include stirred systems (Section 3.2), wave-mixed systems (Section 3.3), and a recently introduced rotating bed bioreactor (Section 3.4) [177]. In actual fact, rotating bed (or wall vessel) bioreactors $[177,178]$ are important for tissue engineering applications aimed at cell differentiation (and not at cell expansion). Pneumatically driven versions such as the $3 \mathrm{~L}$ Air-Wheel bioreactor from PBS Biotech ${ }^{\circledR}[179]$ are excluded, although a poster presentation on Coronado Island recently showed that this bioreactor shows even slightly higher cell expansion rates than a stirred system in MSC expansion runs. More often used are hydraulically driven representatives, which include parallel plate bioreactors (Section 3.5), hollow fiber bioreactors (Section 3.6), and fixed bed bioreactors (Section 3.7), for which power input is generated by pumps.

In the case of the mechanically driven bioreactors, microcarriers (Section 2.1) or perfused plates have so far provided the growth surface for the MSCs. In hydraulically driven bioreactors the cells are grown either on perfused plastic surfaces (Section 3.5), hollow fibers (Section 3.6) or packed particles (Section 3.7). It is worth mentioning that the majority of dynamic bioreactor 
types were originally developed for production processes aimed antibodies and vaccines. For this, genetically modified, continuous mammalian cell lines such as Chinese hamster ovary (CHO) cells are generally grown [180-182]. With the exception of spinner flasks (as simple stirred bioreactors), mechanically driven bioreactors are generally instrumented with sensors to enable monitoring and control of temperature, $\mathrm{pH}$ value, $\mathrm{DO}$ and carbon dioxide concentration, gas and liquid flow rates, impeller or rocking speed.

A second classification trial is based on the number of uses of the bioreactor's cultivation vessel and distinguishes between reusable and single-use bioreactors. Whereas the vessel of a reusable bioreactor is made of glass or stainless steel, single-use bioreactors have a plastic cultivation vessel. This cultivation vessel is pre-assembled, beta-or gamma-irradiated and, then delivered as ready-to-use. After one use, as the vessel is a rigid polystyrene or polycarbonate container or a flexible multilayer bag with contact layers made of polyethylene or ethylene vinyl acetate, it is discarded [183]. For this reason single-use bioreactors are also often referred to as disposable bioreactors. If single-use bioreactors are operated correctly for the production of high value products at small and medium volume scale (as is the case for productions of cell therapeutics), they contribute to savings in time and costs. Furthermore, process flexibility and safety can be increased, which is an advantage in processes where the cells produced are the target product that is directly given to the patient.

Different authors have described adverse effects on $\mathrm{CHO}$ cells grown in polyethylene bags [184-188]. They found poor cell growth arising from leachables such as bis(2.4-di-tert-butylphenyl)phosphate. Such leachables are substances that can migrate from bag layers during processing and leach out into the culture broth in concentrations that are deleterious to cell growth. This phenomenon has not been reported for MSC expansions to date.

There is no doubt that advantages currently prevail if an appropriate single-use bioreactor (regardless of whether it represents a static or dynamic system) is applied for productions of cell therapeutics. This, together with the suitability of single-use bioreactors for commercial production processes with Good Manufacturing Practice (GMP) and regulatory demands, explains their increasing usage. In particular, dynamic systems including stirred, wave-mixed, parallel plate, hollow fiber and fixed bed single-use bioreactors are currently the focus of interest for producers of cell therapeutics.

\subsection{Stirred single-use bioreactors in microcarrier-based MSC expansions}

In stirred single-use bioreactors, mixing is induced by the mechanical agitation of one or more impellers. For research purposes disposable spinner flasks operating with magnetically driven, slowly moving paddle impellers (60 rpm) are most often used [189]. The cells are propagated on microcarriers until working volumes of $250 \mathrm{~mL}$. In contrast to scalable, automated stirred bioreactor versions, spinner flasks are only surface-aerated. Furthermore, spinner cultivations entail availability of incubators for temperature as well as humidity control. Nevertheless, peak viable cell densities of between $6 \cdot 10^{5}$ and $1 \cdot 10^{6}$ cells $\mathrm{mL}^{-1}$ and maximum cell expansion factors between 30 and 50 are achievable in spinner flasks when the culture medium contains serum and is cyclically perfused (by manual partial and periodical medium exchange). This was 
A)

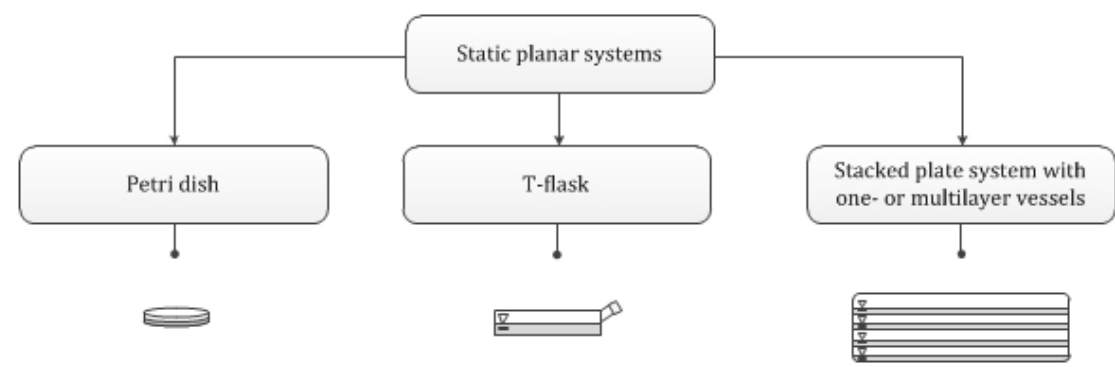

B)

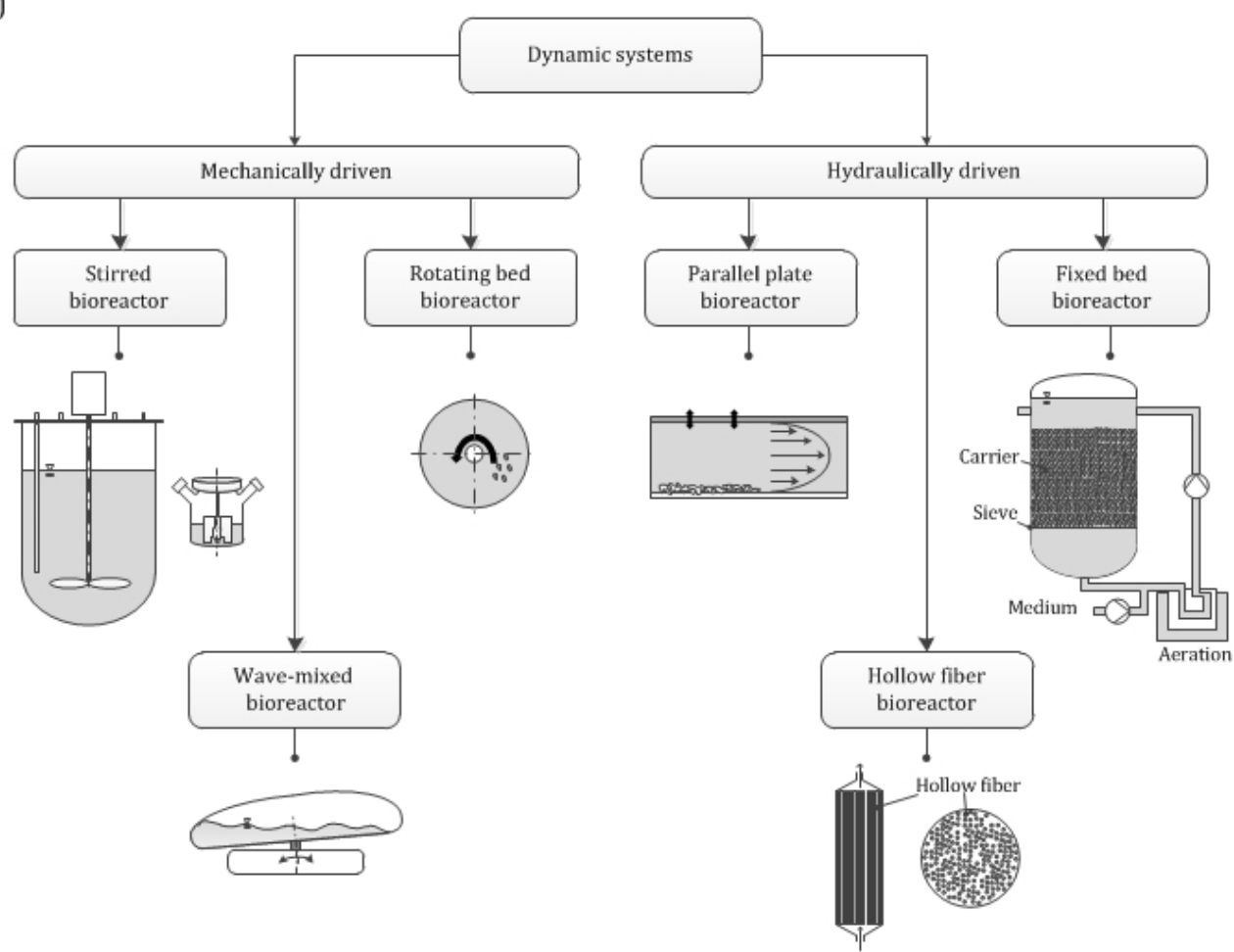

Figure 5. Suitable bioreactors for MSC expansion. Presented classification bases on the power input type.

demonstrated for hADSCs and hBM-MSCs expanded on polystyrene-and gelatin matrix based microcarriers in our lab over a cultivation period of 7 days.

At benchtop scale MSC expansions were successfully carried out in the Mobius ${ }^{\circledR}$ Cell Ready 3L bioreactor (Merck Millipore) and the BIOSTAT ${ }^{\circledR}$ UniVessel 2L SU (Sartorius Stedim Biotech). The key element of both systems is the rigid polycarbonate vessel, contains one or 
two rotating impellers and an aeration device (sparger). The user can choose between plastic vessels having reusable or single-use temperature, $\mathrm{DO}$ and $\mathrm{pH}$ probes.

The Mobius ${ }^{\circledR}$ CellReady bioreactor (maximum working volume of $2.4 \mathrm{~L}$ ) is equipped with a single top-driven marine impeller and an open pipe or micro-sparger. According to its configuration, the main bioengineering parameters were investigated and summarized by Kaiser et al. 2011 [190]. The published results of the bioengineering studies with the Mobius ${ }^{\circledR}$ CellReady 3L show that this system is also usable for MSC expansion. Suitable impeller speeds are adjustable, which enables culture homogeneity while avoiding microcarrier sedimentation, cell differentiation and cell damage that may result from too high shear stress. For hBM-MSCs the accuracy of this hypothesis was demonstrated by the studies of Cierpka et al. [191] and Jing et al. [192]. In cultivations running in serum-supplemented medium (10\% FBS) for between 12 and 14 days, peak viable cell densities between $2.5 \cdot 10^{5}$ and $2.7 \cdot 10^{5}$ cells $\mathrm{mL}^{-1}$ were obtained. Moreover, Stadler [193] and Ott [189] achieved a serum-reduced expansion of hADSCs within 6 days, which was comparable to a $250 \mathrm{~mL}$ reference spinner flask (100 $\mathrm{mL}$ working volume). In spite of reduced cultivation time and serum content, the peak viable cell density was more than double $\left(5.5 \cdot 10^{5} \mathrm{hADSCs} \mathrm{mL}^{-1}\right)$ when compared with the results of Cierpka et al. [191] and Jing et al. [192].

The top-driven UniVessel ${ }^{\circledR}$ SU $2 \mathrm{~L}$ bioreactor (maximum culture volume of $2 \mathrm{~L}$ ) has two 3segment blade impellers and an L-shaped macro-sparger. Similarly to the Mobius ${ }^{\circledR}$ Cell Ready it is hydrodynamically well-characterized [194,195]. Peak viable cell densities between 1.8 $10^{5} \mathrm{hBM}-\mathrm{MSCs} \mathrm{mL}^{-1}$ and $3 \cdot 10^{5} \mathrm{hADSCs} \mathrm{mL}^{-1}$ were determined in serum-supported production processes on cultivation day $9[189,196]$. In order to increase MSC expansion efficiency in the UniVessel SU 2L, Jossen et al. [197] improved the fluid flow while reducing fluid shear stress for cultivations with higher microcarrier amounts. This was accomplished by modifying the standard vessel design (increasing impeller blade angle from $30^{\circ}$ to $45^{\circ}$ and reduction of off-bottom clearance from 0.41 to 0.26 ). As a result, the maximum specific power input was reduced by a factor of 2 and the peak viable cell density was more than 3 times higher than that of the hBM-MSCs, for which a cell expansion factor of 35 was reached.

Recently, the propagation of hADSCs on microcarriers in stirred bag bioreactors exceeding benchtop scale was carried out for the first time. Schirmaier and coauthors [196] worked with Sartorius Stedim `s top-driven BIOSTAT ${ }^{\circledast}$ CultiBag STR 50L, for which there is comprehensive bioengineering characterization [195]. They used the 3-D bag version shown in Figure 7 E (Section 5), in which two 3-segment blade impellers and a micro-sparger have been implemented. Cultivation was executed with $35 \mathrm{~L}$ working volume while realizing a partial medium exchange on day 4 . Growth on polystyrene microcarriers at serum-reduced conditions (in this case, $5 \%$ ) allowed $3 \cdot 10^{8} \mathrm{hADSC}$ to be harvested on cultivation day 9 . This provided the basis for the scale-up approach explicated in Section 5.

\subsection{Potential of wave-mixed bioreactors for microcarrier-based MSC expansions}

MSC expansions have already been carried out in wave-mixed bioreactors, which have a pillow-like culture bag with single-use sensors for temperature, $\mathrm{pH}$ and DO control. The bag is fixed on the rocker platform, which makes a one-dimensional (1-D) oscillatory movement. 
By rocking the platform a wave is induced in the bag, which contains medium and cells. In this way, the medium surface is continuously renewed while bubble-free oxygen is introduced into the culture broth from the headspace of the bag. Wave generation and propagation, and thus mass and energy transfer, in this bioreactor type are dependent on the rocking rate, rocking angle, aeration rate, filling level (50\% maximum) and culture broth viscosity. These parameters affect the fluid flow, mixing time, oxygen mass transfer, shear stress acting on cells, and finally the cultivation result. As discussed by Eibl et al. [198] and Werner et al. [199], shear stress is highest at the lowest filling level together with the highest rocking rate and rocking angle. Indeed, energy dissipation and shear stress pattern were more homogeneous in wavemixed bioreactors with 1-D motion than in stirred cell culture bioreactors with a paddle impeller. For this reason, these wave-mixed bioreactors are well-suited for productions with shear sensitive cells. A further advantage of wave-mixed bioreactors is their negligible foaming, meaning that there is no need for antifoam agents to be added, which also simplifies downstream processing of the product. In addition, protocols for microcarrier-based productions with different continuous mammalian cell lines are available as well as for primary cells known to be very sensitive to shear and difficult to culture (such as T-cells) [200-204].

The first attempts published demonstrate the feasibility of expanding MSCs in $2 \mathrm{~L}$ wave-mixed bags on Cytodex 3-and Cultispher-S-microcarriers. Akerström [205] propagated MSCs over 18 days while feeding carriers on day 11 and 13 into a Wave Bioreactor 2/10 (GE Healthcare). The expansion factors determined after trypsinization were around 6. Timmins et al. [206] achieved expansion factors around 16 on cultivation day 7 when producing MSCs derived from the placenta at reduced $\mathrm{O}_{2}$ levels $(5 \%)$. He published a procedure which was realizable in wave-mixed bioreactors from both GE Healthcare and Sartorius Stedim Biotech.

\subsection{Single-use rotatory bed bioreactors}

An interesting new approach for a perfused dynamic bioreactor represents Zellwerk's rotating bed bioreactor system ZRP [177]. As shown in Figure 6, a cylindrical culture vessel has a rotating bed of polycarbonate plates. Bed rotation is caused by a non-contact magnetic drive coupled to the culture vessel. The culture vessel is equipped with sampling ports and a measuring device with ports for $\mathrm{pH}$ and DO sensors. The external media circulation combined with the rotation of the polycarbonate bed ensures mixing of the culture medium. To provide an oxygen supply, the overlay atmosphere of the headspace of the vessel is aerated with $\mathrm{CO}_{2}$, $\mathrm{N}_{2}$ and air. All cultivation parameters such as $\mathrm{pH}, \mathrm{DO}$, temperature and bed rotation are monitored online and regulated by a control unit. Reichardt et al. demonstrated a 39 fold expansion of cells derived from human umbilical cord arteries in 9 days [177].

\subsection{Single-use parallel plate bioreactors}

Whereas stirred and wave-mixed bioreactors used for the expansion of MSCs are operated with microcarriers in fed batch mode (feeding or partial medium exchange), parallel plate bioreactors run carrier-free and in continuous perfusion mode. Single-use parallel plate bioreactors have a modular multiplate design. The plates are typically made from polystyrene, whereby each plate consists of two compartments separated by a gas-permeable membrane 


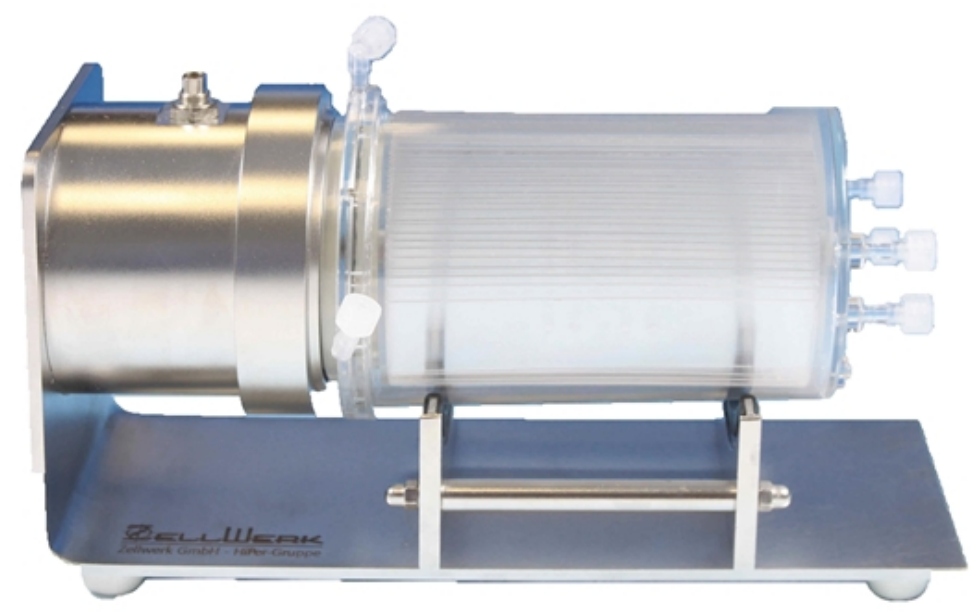

Figure 6. The rotating bed bioreactor system. The bioreactor system is composed of a cylindrical culture vessel and an integrated bed of polycarbonate plates with a cell culture surface area of up to $6000 \mathrm{~cm}^{2}$ (with courtesy of Zellwerk Gmbh; Oberkrämer, Germany).

(that is impermeable to liquids) [207]. Whereas the upper compartment is filled with air, the bottom compartment contains the cells. The cells grow on the plastic surface of the bottom compartment as monolayer (2-D growth) while being continuously supplied with culture medium.

In general, plate bioreactors have been well-investigated in terms of shear stress, which is regarded to be low in their case. In 1996 Peng and Palsson [208] studied the influence of their geometry on fluid flow and the resulting growth and differentiation of bone marrow-derived stem cells. They found a superiority of radial flow and ascribed this finding to the uniform environment caused by the hyperbolic velocity and tube-like shear stress contribution. Due to the absence of walls in the flow path and the location of the boundary walls parallel to the flow direction, slow flowing regions were obtained on the growth surface of radial flow-type parallel plate bioreactors.

Prominent representatives of single-use parallel plate bioreactors are Corning 's E-Cube ${ }^{\mathrm{TM}}$ System and Pall's Integrity ${ }^{\mathrm{TM}}$ Xpansion $^{\mathrm{TM}}$ Multiplate Bioreactor. The E-Cube, which is available with 10-or 25-stack modules requires an incubator for operation. It offers a maximum growth surface of $21,250 \mathrm{~cm}^{2}$. The Integrity ${ }^{\mathrm{TM}}$ Xpansion Multiplate Bioreactor is a selfcontained bioreactor system that is obtainable with 10 up to 200 plates and provides a maximum growth surface of $122,400 \mathrm{~cm}^{2}$. Its gas exchange is realized in a central column with channels along the plates through which the medium circulates. CFD studies realized with the Integrity ${ }^{\mathrm{TM}}$ Xpansion ${ }^{\mathrm{TM}}$ Multiplate Bioreactor revealed the occurrence of gentle laminar flow. Maximum wall shear stress did not exceed $10 \mathrm{mPA}$, which was up to 1000 times lower than in stirred bioreactors (personal communication W. Kuhlmann, ATMI Life Sciences, June 2013). 
Bone marrow-derived MSCs have been successfully expanded without differentiation in this single-use bioreactor type, which generally allows production of up to a billion cells per batch. By using holographic microscopy in cultivations with the Integrity ${ }^{\mathrm{TM}} \mathrm{Xpansion}^{\mathrm{TM}}$ Bioreactor, cell morphology can be monitored on the 10 top plates. Normally, the lack of opportunity to monitor cells is regarded as a drawback of parallel plate bioreactors [209].

\subsection{Hollow fiber bioreactors in MSC expansion procedures}

Similarly to parallel plate bioreactors, hollow fiber bioreactors provide a low shear stress environment [210] and cell propagation in continuous perfusion mode. Hollow fiber bioreactors are characterized by a high surface area-to-volume ratio $\left(100-200 \mathrm{~cm}^{2} \mathrm{~mL}^{-1}\right)$ and create 3$\mathrm{D}$ environment for cells. They consist of a bundle of parallel hollow fibers constructed from cellulosic, polysulfone, polypropylene or polyethylene materials, which are encased in a cylindrical polycarbonate cartridge with ports for flow around the fibers. The pore size of the semi-permeable hollow fiber membrane determines which molecular species are rejected.

The beginning of hollow fiber technology dates back to the early 1970s [211], when Knazek and his team used tubular membranes upon which cells were able to expand to high cell densities $\left(10^{7}\right.$ to $10^{8}$ cells $\left.\mathrm{mL}^{-1}\right)$ and which were impermeable to the cells. Analogically, the fiber matrix was permeable to gases, nutrients and metabolic waste products. Cells suspended in the culture medium settled on the outer surfaces of hollow fibers while oxygenated culture medium flowed continuously through the fibers. Medium nutrients diffused through the fiber wall into the cells and metabolic waste products diffused from the cells through the fiber wall into the perfused liquid.

Since then, hollow fiber bioreactors have been improved and used extensively, for example to expand lymphocytes [212,213], to produce glycoproteins (in particular, antibodies) and viruses [214-221], to cultivate hepatocytes and as extracorporeal assist devices [222-224]. Modules were designed which distributed the main fluid flow equally to each hollow fiber in the bundle [225]. This generated a parabolic velocity profile in the fiber lumen and resulted in uniform shear stress for the attached cells, which was directly proportional to the intracapillary flow rate $[211,212]$. Cell adhesion was enhanced by pre-coating the hollow fibers with one or even more extracellular matrix proteins such as fibronectin or collagen [226].

The use of hollow fiber bioreactors to produce clinically relevant numbers of MSCs (total cell yields between $10^{8}$ and $10^{9}$ cells) has been reported in numerous studies [227]. These cell amounts are sufficient for autologous and selected allogeneic therapies. Exemplarily, we would like to refer to serum-supplemented productions recently performed with the FiberCell System (FiberCell Systems, max. growth surface of $2.5 \mathrm{~m}^{2}$ ) and the Quantum Cell Expansion System (Caridian BCT, maximum growth surface of $2.1 \mathrm{~m}^{2}$ ). The articles describe expansion of MSCs isolated from human bone marrow and placenta over a few weeks [210,228-230]. Nonetheless, hollow fiber bioreactors and fixed bed bioreactors subsequently described are restricted in scalability. They both have limitations in that their nutrient and oxygen gradients in culture restrict the length of the fiber and height of the fixed bed. The biggest challenge, however, for both reactor types is posed by cell harvest. 


\subsection{Single-use versions of fixed bed bioreactors and MSC expansions}

Initial work with fixed bed bioreactors (also referred to as packed bed bioreactors) and mammalian cells started in the 1950s. In fixed bed bioreactors cells are immobilized on or encapsulated in a stationary matrix consisting of particles densely packed in a cylindrical vessel. Several types of particles have been used to date: Macro-porous microcarriers, porous ceramic beads, porous glass beads, glass fibers, polyester discs, alginate beads and hydrogels [62,231-236]. The culture medium is perfused through the bed of the bioreactor and supplies cells with nutrients while removing undesired metabolites. For this purpose, either an external medium reservoir is used or the culture medium is circulated in an internal loop. When fixed bed bioreactors are run in continuous perfusion mode, cell densities of around $510^{8}$ cells $\mathrm{mL}^{-1}$ can be achieved. Knowledge about configurations of fixed bed bioreactors and their bioengineering characteristics was summarized by Warnrock et al. [232].

Fixed bed bioreactors have been successfully employed in different investigations with primary cells, such as bioartifical liver support systems and stem cell expansions. It is a wellknown fact that the company Pluristem Therapeutics, a leading developer of placenta-based cell therapeutics, uses reusable fixed bed bioreactors (PluriX 3-D bioreactors) in combination with Fibra-Cel ${ }^{\circledR}$ disks. Fibra-Cel ${ }^{\circledR}$ disk carriers are characterized by high porosity and composed of two layers of non-woven polyester and polypropylene [236,237]. These fiber carriers also form the fixed bed in Eppendorf's single-use version of the BioBLU ${ }^{\circledR}$ bioreactor, which is obtainable up to a vessel volume of 5L. When pre-loaded with $150 \mathrm{~g}$ of Fibra-Cel ${ }^{\circledR}$ disks, 0.12 $\mathrm{m}^{2}$ of effective surface area per gram of disks is provided. The largest single-use fixed bed bioreactor is Pall's Integrity ${ }^{\mathrm{TM}} \mathrm{iCELLis}^{\mathrm{TM}}$ bioreactor, which has a maximum growth surface of $500 \mathrm{~m}^{2}$ and a fixed bed made from polyethylene terephthalate microfibers [238]. But as in the case of the BioBLU ${ }^{\circledR}$ SU bioreactor, no reviewed literature about MSC cultivation in the Integrity $^{\mathrm{TM}}$ iCELLis $^{\mathrm{TM}}$ was found at the time of writing, with the exception of an mL-scale application in which a single-use fixed bed bioreactor was used. This concerned a syringe-like fixed bed bioreactor for the cultivation of implantable immortalized hMSCs expanded on alginate beads and applied in cell therapy trials for stroke treatment $[1,239]$.

\section{Scale up of MSC cultivations: General considerations}

In planar cultures, the growth of the adherent cells has to date been limited by the available growth surface area, which is determined by the geometry of the cultivation vessel. Scaling up of planar static cultures is therefore realized by increasing the growth surface (linear scaleup), either by working with several bioreactors in parallel and/or using multilayer systems. However, as already pointed out in Section 3, with an increasing number of layers and/or bioreactors the risk of contamination and vessel-to-vessel variance rises. It is assumed that lot size of planar culture systems are capped at $1-410^{11}$ cells, whereby lot sizes of $>110^{11}$ cells are not readily achievable without massive automation and parallel processing [174].

The available growth surface area also limits the lot sizes in dynamic parallel plate, hollow fiber bioreactors and fixed bed bioreactors, whereas concentration and temperature gradients 
are less likely in these systems because of the convective transport. Due to the limited engineering data available for these systems, no systematic scale-up studies have been published so far and scaling-up is mainly realized using trial-and-error methods. In contrast, several scaleup rules have now been accepted for stirred bioreactors which is why the main focus of the following is on this bioreactor type. Since it is not possible to simultaneously maintain identical operational characteristics such as mixing time, power input, impeller speed, carbon dioxide removal and oxygen mass transfer over the different scales, the most important factor(s) has (have) to be identified.

In biopharmaceutical production processes, the impeller tip speed $\left(\mathrm{u}_{\mathrm{tip}}\right)$ is a frequently used scale-up criterion [240,241], which is directly proportional to the impeller diameter and the rotational speed. Typically, the impeller tip speed correlates well with the maximum fluid velocities, and consequently, the maximum shear stresses, as long as low aeration rates are used. Otherwise, local shear stresses from rising bubbles and/or bursting bubbles at the liquid surface may exceed impeller-induced shear by several orders of magnitude [242]. Based on model devices, non-lethal responses of hMSCs on shear stresses, including changes in gene expression, signaling pathways and morphology as well as cell differentiation, have been reported over a wide range of shear from 0.01 to $5 \mathrm{~Pa}[138,145,146,152,243]$, depending on the cell source and donor as well as the experimental setup (used device, exposure time, medium etc.).

However, the impeller tip speed does not account for the actual impeller type nor volume changes during the process (e.g. by feeding or medium exchange). Particularly at larger scales, heterogeneity in the culture environment due to gradients in dissolved gases and metabolites can become an issue. Another possible scale-up criterion is the mixing time [244]. Based on the turbulence theory, the mixing time was suggested to be independent of impeller type and was found to correlate with specific power input and geometrical parameters such as the impeller and vessel diameter and the filling height, which is valid for single impellers in draw and fill mode as well as multi-stage impellers [245]. In comparative studies with different stirred single-use bioreactors, mixing times of between approximately $44 \mathrm{~s}$ and $86 \mathrm{~s}$ for a constant tip speed of $0.5 \mathrm{~m} \mathrm{~s}^{-1}$ were found [246]. In single-use bioreactors there is still a lack of systematic comparisons of mixing that take geometric parameters into account. Furthermore, it should be emphasized that keeping mixing time constant during scaling-up results in significant increases in specific power input at larger scales [247,248].

For cells growing in suspension, the most frequently used scale-up criterion is the specific power input, which can be predicted from the impeller power number $(\mathrm{Ne})$ according to $\mathrm{Eq}$. 9, where $\varrho_{f l}, n_{R}, d_{R}$ and $V_{L}$ represent liquid density, the impeller speed, the impeller diameter and the liquid volume respectively.

$$
P / V=\frac{N e \rho_{f l} n_{R}{ }^{3} d_{R}{ }^{5}}{V_{L}}
$$


The power number is specific for each impeller type and depends on the Reynolds number (Re), which was introduced in Section 2.2. In general, radial flow impellers exhibit greater power numbers than axial flow impellers, which therefore need to rotate more quickly in order to achieve the same power input (see Eq. 11). Reported power numbers for stirred single-use bioreactors range from 0.3 (Mobius ${ }^{\circledR}$ CellReady 3L) to 4.2 (Mobius ${ }^{\circledR}$ CellReady 50/200L), whereas the UniVessel SU 2L with two segment blade impellers has a power number of 1.1 [249].

For microcarrier-based processes, suspension criteria $\left(\mathrm{N}_{\mathrm{S} 1}\right.$ and $\left.\mathrm{N}_{\mathrm{S} 1 \mathrm{U}}\right)$ have been proposed for scaling-up, since they provide effective use of the available growth surface of the microcarriers. Both suspension parameters, which describe the impeller speed required to bring solid particles (the microcarriers) into suspension, were introduced more than 50 years ago [250-252], although their potential for microcarrier-based stem cell expansions and their scale-up was only reported quite recently [119]. The $N_{S 1}$ criterion displays the impeller speed at which all particles are just fully suspended, whereby a homogeneous dispersion of all microcarriers is not a necessary consequence. The $\mathrm{N}_{\mathrm{S1U}}$ criterion is its lower limit and thus the impeller speed required to locate the particles at the bottom of the bioreactor with none of them at rest. Comparing different stirred SU bioreactors from small to pilot scale, the lowest impeller speeds, and, thereby power inputs required to lift up polystyrene-based microcarriers with solid fractions of up $0.2 \%$ were found in the Mobius ${ }^{\circledR}$ CellReady bioreactor [182]. However, the suspension criteria also strongly depend on the microcarrier type used. Thus, they should be determined as part of process development for each individual process (see also Section 5.3).

Other agitation-related scale-up factors such as the Reynolds number or Kolmogorov's microscale of turbulence are more seldom used in scale-up studies. Because of the low oxygen demands of hMSCs $\left(1.2-3.810^{-17} \mathrm{~mol}_{\text {oxygen s}}{ }^{-1}\right.$ cell $\left.^{-1}\right)[253,254]$ and the relatively low cell density, the volumetric oxygen demand can often be covered by surface aeration. Therefore, scale-up factors related to oxygen mass transfer, such as the specific oxygen transfer coefficient $\left(k_{\mathrm{L}} \mathrm{a}\right)$, are also considered to be less important. However, they may increase in importance at increasing scales and higher cell densities.

\section{A new scale-up approach for expanding hMSCs}

\subsection{Motivation}

In this section, we introduce a new scale-up approach and show its suitability for rapid and efficient expansion of hADSCs (Figure 7 A) and hBM-MSCs (Figure 7 B). Both cell types are of therapeutic interest as the increasing number of clinical trials presented on www.ClinicalTrials.gov indicates. There is no doubt that alternatives to planar systems are required. Although, vessel versions with 10-or 40-layer units providing cell yields between $2 \cdot 10^{8}$ and $1 \cdot 10^{9}$ cells [31] have been established, a consistently high cell quality at high cell numbers is 
difficult to ensure. This explains the shift to suspension cultures, particularly using microcarriers and stirred instrumented bioreactors, when scalable hMSC production is the focus.

Our scale-up strategy (Figure 7), which was aimed at cell yields around $1 \cdot 10^{10} \mathrm{hMSC}$ and expansion factors exceeding 30, is based on two pillars: (i) screening studies performed in Corning spinners (Figure $7 \mathrm{C}$ ) at $\mathrm{mL}$-scale and (ii) bioengineering investigations carried out for the spinner system and the pilot bioreactor system chosen (Figure 7 D and Figure 7 E). The bioengineering studies of both cultivation systems included CFD simulations and result verification by Particle Image Velocimetry (PIV). Their aim was to predict fluid flow pattern and fluid flow velocities to enable calculation of local shear stress distributions, turbulent dissipation rates and Kolmogorov`s micro-scales.

Together with the microcarrier distributions, these parameters were considered in order to predict optimum impeller speeds while avoiding high shear stresses, which finally result in cell differentiation or even cell death. As proposed by Kaiser et al. [255] the suspension criteria $\mathrm{N}_{\mathrm{S} 1}$ and $\mathrm{N}_{\mathrm{S1U}}$ were employed to transfer the process from $100 \mathrm{~mL}$ to $35 \mathrm{~L}$ and $50 \mathrm{~L}$ working volumes, respectively.

It is worth mentioning that all the cultivations ran between 6 and 9 days and were executed in fed batch mode at low-serum conditions. Reducing the serum-content in the culture medium or using serum-free or chemically defined culture media contributes to process cost reductions, and simplifies downstream processing and product approval $[65,256]$. The two cell types used were provided by the Lonza Cologne $\mathrm{GmbH}$, Germany. They were each cryopreserved (second passage, population doubling level of 10) and originated from a single consenting, informed donor. In all hMSC production processes, daily sampling and sample analyses in accordance with the descriptions of Schirmaier et al. [196] and Jossen et al. [197], were executed. In addition to the determination of cell density, viability, concentrations of glucose, lactate, glutamine and ammonia, flow cytometric and apoptotic investigations were performed.

\subsection{Investigations at $\mathrm{mL}-\mathrm{scale}$}

In total, seven different culture media from different suppliers with varying contents of FBS (0-10\%) and six different microcarrier types (different densities and diameters) were used in the comprehensive spinner screening. The results for both hMSC types (cell growth, substrate and metabolite courses and cell expansion factors) achieved in the Corning spinners and 2layer Corning CellSTACKs, were compared with those of cultivations in standard DMEM (Dulbecco's Modified Eagle Medium) with $10 \%$ FBS. While propagating the cells at microcarrier solid fractions of $1.43 \%$ (polystyrene matrix-based microcarriers) and $0.3 \%$ (gelatin matrix-based microcarriers) over 6 days, the culture broth was stirred intermittently or continuously at $60 \mathrm{rpm}\left(37^{\circ} \mathrm{C}, 5 \% \mathrm{CO}_{2}\right.$ and $80 \%$ humidity). This impeller speed had been previously determined in spinner experiments aimed at cell yield optimizations in standard DMEM medium containing $10 \%$ FBS. Serum-free expansion (0 \% FBS) of both cell types was possible, but the expansion factors achieved were below 10 and regarded as insufficient. Lonza 


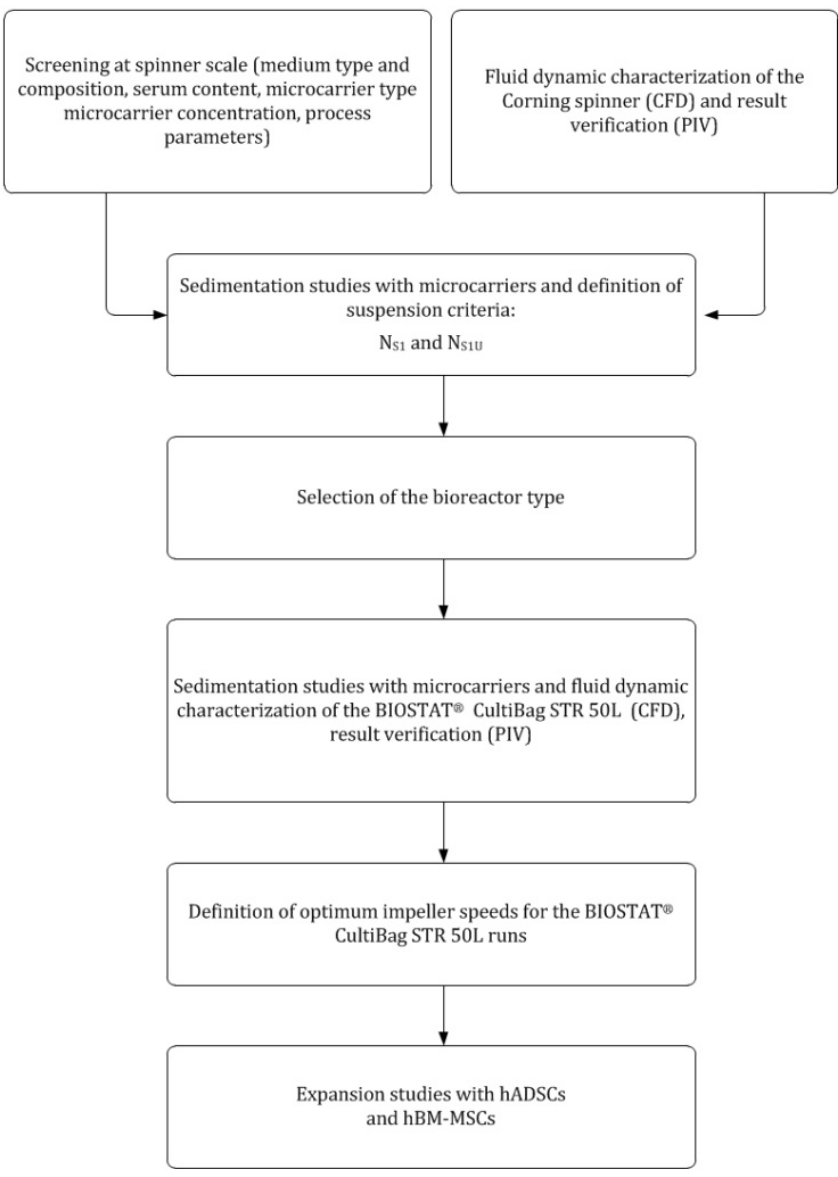

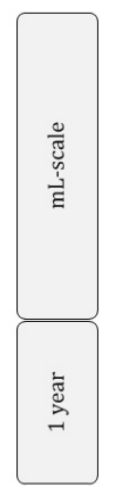

A)

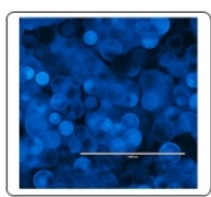

B)

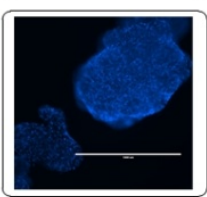

C)

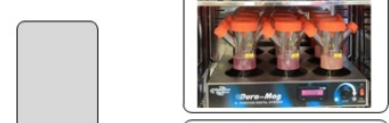

D)
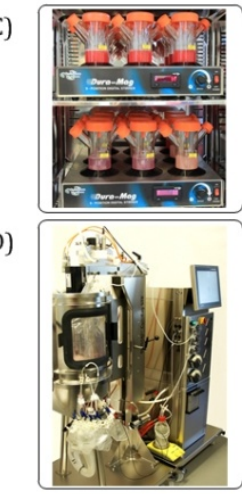

E)

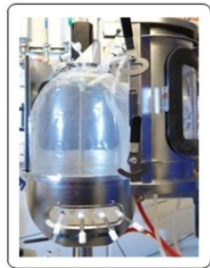

Figure 7. Our expansion approach with (A) DAPI staining of microcarriers realized in hADSC expansions with polystyrene-based carriers in the BIOSTAT ${ }^{\circledR}$ CultiBag STR 50L on cultivation day 7 (0.71\% solid fraction), (B) DAPI staining of microcarriers realized in hBM-MSC expansions with gelatin-based carriers in the BIOSTAT ${ }^{\circledast}$ CultiBag on cultivation day 7 (0.21\% solid fraction), (C) $125 \mathrm{~mL}$ spinner flasks equipped with top-mounted blade impeller with diameter of $41.5 \mathrm{~mm}$ and operated with $100 \mathrm{~mL}$ working volume, (D) BIOSTAT ${ }^{\circledast}$ CultiBag STR 50L during one experimental run and (E) its polyethylene multilayer bag in which two 3-segment blade impellers with a diameter of 143 $\mathrm{mm}$, a microsparger, and single-use $\mathrm{pH}$-and DO-probes were implemented. The bag have being fixed and shaped by a stainless steel support container. Scale bars in (A) and (B) indicate $1000 \mathrm{~m}$.

stem cell medium provided the most promising results and allowed satisfactory growth at low serum-content (5 \% FBS) and at continuous stirring, when hADSCs were propagated on the polystyrene carriers and hBM-MSCs expanded on the gelatin carriers with the lower density. A further improvement in the cell expansion factor (60 instead of 40) and the maximum cell yield $\left(1 \cdot 10^{8}\right.$ cells instead of $4 \cdot 10^{7}$ cells) was achieved by: (1) modifying the Lonza stem cell 
medium and realizing one single feed (with a feeding solution) instead of performing a single $50 \%$ medium exchange between day 3 and 4, (2) increasing the inoculum density and (3) increasing the microcarrier concentration.

The transfer of fluid flow at the optimum cultivation conditions found in the spinner presupposed CFD modeling. To date, several studies have demonstrated the usefulness of CFD in analyzing fluid dynamics at both micros-and macroscopic levels in stem cell bioreactors [132, 255 ,257]. We modeled the fluid flow inside the Corning spinner flask by using the finite volume solver Fluent from ANSYS (ANSYS Inc., version 14.0, USA) and calculated the three local velocity gradients as well as their magnitude. For more detailed information the interested reader is referred to Kaiser et al. [255]. As exemplarily shown in Figure 8 for $60 \mathrm{rpm}$ and 100 $\mathrm{mL}$ working volume, the flow in the spinner flask was primary tangential with low axial and radial velocity components. Due to the wide impeller blade and the absence of baffles, the observation that the tangential velocity was the highest velocity component comes as no surprise. As also expected the velocities were highest at the edges of the impeller blade as well as at the tips of the impeller bars and correlated directly with $\mathrm{u}_{\text {tip }}$. In contrast, the lowest velocities were determined below the impeller and near the vessel wall. It was also found that sedimentation and agglomeration of the microcarriers were most likely to occur below the impeller bar. This finding was also confirmed by the microcarrier distribution in the spinner flasks, which is depicted in Figure 9. Furthermore, at $60 \mathrm{rpm}$ and $100 \mathrm{~mL}$ working volume the mean local shear stress level $\left(\tau_{n t}\right)$ was $4 \cdot 10^{-3} \mathrm{~N} \cdot \mathrm{m}^{-2}$ and the maximum value was estimated to be $0.2 \mathrm{~N} \cdot \mathrm{m}^{-2}$. The mean turbulent energy dissipation rate $(\varepsilon)$ was $1.1 \cdot 10^{-3} \mathrm{~m}^{2} \cdot \mathrm{s}^{-3}$ and the maximum turbulent energy dissipation rate was about 10 times higher. The mean and minimum Kolmogorov's microscales of turbulence were $60 \mu \mathrm{m}$ and $191 \mu \mathrm{m}$, respectively. However, we would like to point out that Kolmogorov's theory is only valid for high turbulence $\left(\operatorname{Re} \geq 10^{4}\right)$ and because Re was 1722 under the process conditions used, the Kolmogorov's values estimated should be viewed critically.

As various mathematical models are available for the simulation of fluid flow in a stirred bioreactor system, the CFD-predicted fluid flow pattern and fluid velocities need to be verified. For this purpose different analytical methods can be used, PIV representing one of those most frequently applied. Its advantages are given by the contactless measuring principle, in which a $1 \mathrm{~mm}$ thick laser sheet is generated by a double-pulsed Nd:YAG laser (wavelength $\lambda=532 \mathrm{~nm}$ ). By adding rhodamine-coated fluorescent particles to the reactor volume, the fluid flow can be visualized and fluid velocities can be measured by recording a set of double images with a small time offset (cross correlation). More detailed representations of this method can be found in [255] and [132]. As exemplarily shown in Figure $8 \mathrm{C}$ for the Corning spinner flask in two vertical positions (below and above the impeller), the CFD-predicted tangential fluid velocities are in good agreement with the PIV-measured data with relative deviations below $7 \%$. These results illustrate that the fluid velocities are well-captured by the CFD model and the model is therefore suitable.

In order to determine the microcarrier distribution, the single-phase model was extended by an additional Eulerian phase (Euler-Euler RANS approach), which also takes the microcarrier into account as a solid phase [255]. Figure 9 illustrates the microcarrier distribution of the 
A

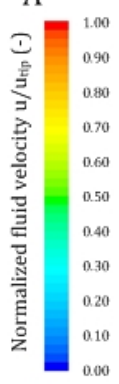

B

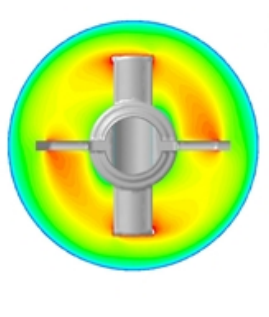

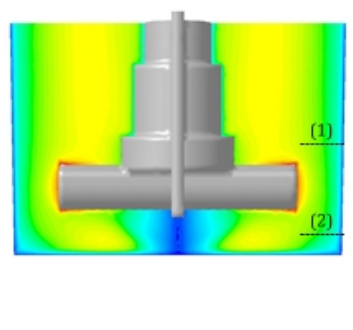

C

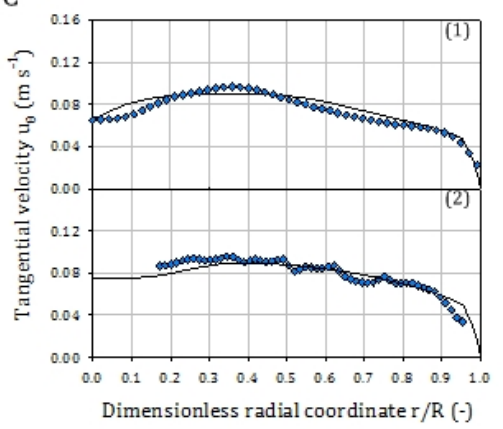

Figure 8. Fluid flow conditions in the Corning spinner flask at $60 \mathrm{rpm}$ and $100 \mathrm{~mL}$ working volume. The fluid flow is presented as a combined vector-contour plot along a horizontal plane (A) and as normal contour plot along a vertical plane (B). The graph (C) illustrates the good agreement between the CFD-predicted (-) and PIV-measured $(\bullet)$ fluid velocities along the radial coordinates in two vertical positions below and above the impeller bar.

polystyrene-type carrier at stirrer speeds below and similar to the $\mathrm{N}_{\mathrm{SIU}}$ criterion. As previously mentioned, the microcarrier sedimentation and agglomeration is most likely to be found below the impeller bar, especially at lower impeller speeds $\left(\mathrm{N}<\mathrm{N}_{\mathrm{S1U}}\right.$ and $\left.\mathrm{N}_{\mathrm{S} 1}\right)$. At these conditions, the cells on the microcarriers, particularly those in the centre of the deposit are not well supplied with nutrients and oxygen. Thus, a mass transfer limitation and a gradient formation can occur, which may have a negative effect on cell quantity and quality. Both limitations can be reduced, or even prevented by increasing the impeller speed. However, this involves raising the specific power input in the bioreactor, thereby increasing the shear stress acting on cells. Consequently, impeller speeds are required that guarantee sufficient mixing at power inputs tolerated by cells without differentiation or dying off. Process conditions which fulfill these requirements are obtained at specific suspension criteria $\left(\mathrm{N}_{\mathrm{S} 1}\right.$ and $\left.\mathrm{N}_{\mathrm{S} 1 \mathrm{U}}\right)$. By increasing the impeller speed to the $\mathrm{N}_{\mathrm{SIU}}$ criterion, the deposit directly below the impeller bar can be reduced to a state in which only a few microcarriers are situated directly below the impeller, with none of them at rest (local microcarrier movement along the bioreactor bottom). This can be seen in Figure $9 \mathrm{C}$, where a decrease in the local volume fraction of the microcarriers from around 0.4 $\%$ to $0.1 \%$ below the impeller bar is shown. Compared to the $\mathrm{N}_{\mathrm{S} 1}$ criterion, where the microcarriers are not in contact with the reactor bottom for more than one second, the $\mathrm{N}_{\mathrm{SIU}}$ provides more gentle conditions for the cells. However, both criteria strongly depend on the characteristics of the microcarrier type (density, diameter, porosity) and the bioreactor (dimension/ configuration). Accordingly, the suspension criteria needed to be determined for each microcarrier and bioreactor used in the expansions.

The $\mathrm{N}_{\mathrm{S} 1 \mathrm{U}}$ and $\mathrm{N}_{\mathrm{S} 1}$ criteria determined for the polystyrene matrix-based microcarriers (solid fraction: $0.25-2 \%$ ) were in a range of $34-50 \mathrm{rpm}$ and $44-61 \mathrm{rpm}$ respectively, and for the gelatine matrix-based microcarriers (solid fraction: 0.25 - 1\%) $59-79 \mathrm{rpm}$ and $80-93 \mathrm{rpm}$ respectively. Indeed, the $\mathrm{N}_{\mathrm{Slu}}$ criterion was always achieved at $20 \pm 4 \%$ lower impeller speeds, which indicates reproducible determinability of the $\mathrm{N}_{\mathrm{SIU}}$ criterion. 
A)

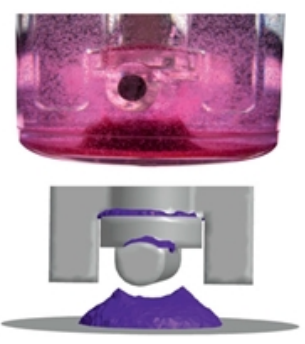

$\mathrm{N}<\mathrm{N}_{\mathrm{SIU}}$
B)

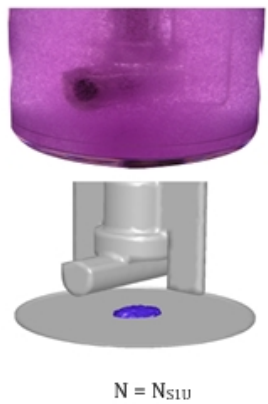

C)

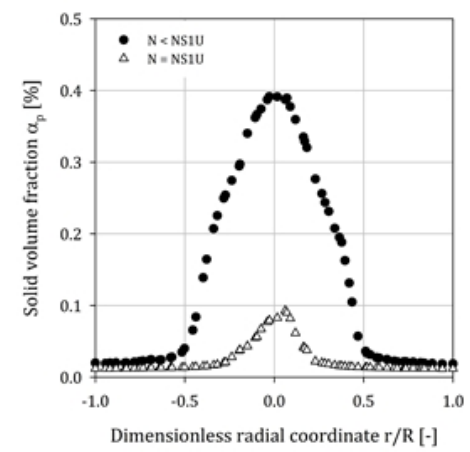

Figure 9. CFD-predicted, and experimentally observed microcarrier distributions for the Corning spinner flask at stirrer speeds below (A) and similar to (B) the $\mathrm{N}_{\mathrm{SIU}}$ criterion. Good agreement is achieved between the CFD-predicted and experimentally observed microcarriers distributions. (C) The graph illustrates the reduction of the microcarrier volume fraction below the impeller from $0.4 \%$ to $0.1 \%$ by increasing the impeller speed to the suspension criterion $\left(\mathrm{N}_{\mathrm{S} 1 \mathrm{U}}\right)$.

\subsection{Investigations at L-scale}

Generation of hMSCs in clinically relevant numbers requires an increase in growth surface as well as in a bioreactor`s working volume. Because Sartorius`s BIOSTAT ${ }^{\circledast}$ CultiBag STR family is commercially available up to $\mathrm{m}^{3}$ scale, and bioengineering data are available for the $50 \mathrm{~L}$, $200 \mathrm{~L}, 1 \mathrm{~m}^{3}$ and $2 \mathrm{~m}^{3}$ versions [194,258], we decided to realize the process scale-up in the BIOSTAT $^{\circledR}$ CultiBag STR 50L. For the preliminary investigations at mL-scale, which demonstrated the usefulness of the suspension criteria for the microcarrier-based stem cell cultivation [255], $\mathrm{N}_{\mathrm{S} 1 \mathrm{U}}$ and $\mathrm{N}_{\mathrm{S} 1}$ were experimentally determined for the BIOSTAT ${ }^{\circledast}$ CultiBag STR 50L in a first step. For this purpose a Plexiglas model with the dimensions of the bag holder (which allowed visual evaluation of the suspension criteria) was used instead of the flexible multilayer bag (Figure $7 \mathrm{E}$ ). More detailed information on the PIV measurement principle applied is given by Schirmaier et al. [196].

In order to achieve the target cell yields, the growth surface was increased accordingly, whereby microcarrier solid fractions of $0.20-1.25 \%$ (polystyrene microcarriers) and $0.1-0.4$ $\%$ (gelatin matrix-based microcarriers) were employed in the suspension studies. The impeller speeds required to ensure the suspension criteria $\left(\mathrm{N}_{\mathrm{S1U}}, \mathrm{N}_{\mathrm{S1}}\right)$ were in a range of $40-66 \mathrm{rpm}$ and $50-77 \mathrm{rpm}$ for the polystyrene microcarriers. In the case of the gelatin matrix-based microcarriers, values ranging from $52-68 \mathrm{rpm}$ and $63-79 \mathrm{rpm}$ were required. Nevertheless, for both hMSC types a comparable correlation (20 $\pm 5 \%)$ between the suspension criteria in the spinner flask and the BIOSTAT ${ }^{\circledR}$ CultiBag STR 50L was detected. Based on the estimated impeller speeds, single-and multi-phase CFD simulations were performed in order to investigate the fluid flow (flow pattern, fluid velocities) as well as to predict the specific power inputs and the shear gradients in the BIOSTAT ${ }^{\circledR}$ CultiBag STR 50L. As illustrated in Figure 10 $\mathrm{A}$ and B the fluid flow in the BIOSTAT ${ }^{\circledR}$ CultiBag STR 50L was primary axial with two flow 
loops, whereby the axial fluid velocities at the bottom of the bioreactor enabled the microcarriers to swirl up. Due to the distinctive axial flow characteristics, which were caused by the two 3-segment blade impellers, as well as the relatively high axial velocities near the reactor bottom $\left(0.04-0.1 \cdot \mathrm{u}_{\mathrm{tip}}\right)$, the microcarriers swirled up even at relatively low impeller speeds. Similarly, the prevalence of the axial fluid flow was obvious from PIV measurement data, where a good agreement between the CFD-predicted and the PIV-measured fluid velocities (relative deviation $<10 \%$ ) was achieved [258].

A)

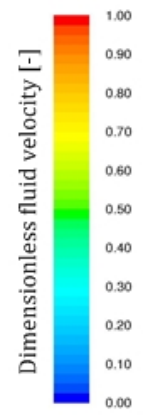

B)

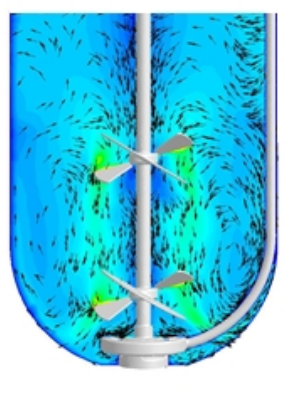

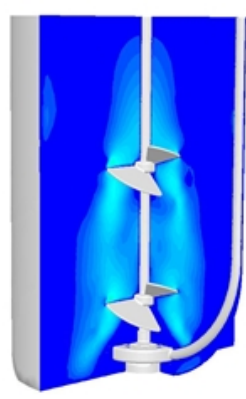

C)

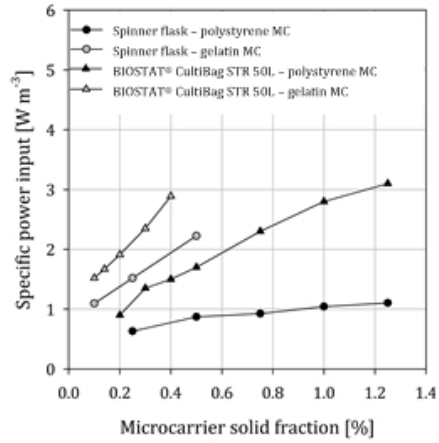

Figure 10. Fluid flow conditions and required specific power inputs for the $\mathrm{N}_{\mathrm{S} 1 \mathrm{U}}$ criterion in the BIOSTAT ${ }^{\circledR}$ CultiBag STR 50L. The contour and vector-plots are given along the mid-reactor plane. The contour plot (A) illustrates that the induced fluid flow in the BIOSTAT ${ }^{\circledast}$ CultiBag STR 50L is primary axial with two flow loops, whereby the axial fluid velocities (B) impinge on the reactor bottom and enable the microcarriers to swirl up. (C) The specific power inputs required to fulfill the $\mathrm{N}_{\mathrm{S} 1 \mathrm{U}}$ criterion are in a comparable range for both the spinner flask and the BIOSTAT ${ }^{\circledR} \mathrm{CultiBag}$ STR 50L.

The suspension studies showed that the number of impellers has no significant effect on the suspension criteria. Thus, fed batch strategies can be realized which start with low working volumes and where only the lower impeller is immersed in culture medium. As is depicted in Figure $10 \mathrm{C}$, the CFD-predicted specific power inputs for the $\mathrm{N}_{\mathrm{S} 1}$ criterion at different microcarrier solid fractions in the BIOSTAT ${ }^{\circledR}$ CultiBag STR 50L were slightly higher $(20-180 \%)$ than in the spinner flask. However, the specific power inputs required were in the same magnitude and appropriate for the microcarrier solid fraction range desired. A closer look the local maximum shear stress levels $\left(1.06 \mathrm{~N} \cdot \mathrm{m}^{-2}\right)$ at $60 \mathrm{rpm}(0.4 \%$ and $0.2 \%$ solid fraction of polystyrene and gelatine matrix-based microcarriers respectively) also revealed a slightly higher stress on the cells grown in the BIOSTAT ${ }^{\circledR}$ CultiBag STR 50L. However, these higher shear stresses occured only in a low percentage $\left(3.15 \cdot 10^{-5} \%\right)$ of the volume and the cells were only exposed to these conditions for a short time. Beyond that, the local mean shear stress levels were in a range comparable to that in the spinner flask, which indicates a broader distribution of the local shear stresses in the BIOSTAT ${ }^{\circledast}$ CultiBag STR 50L $[196,258]$. The fluid flow in the BIOSTAT $^{\circledR}$ CultiBag STR was more turbulent $(\mathrm{Re}=13591-26817)$ than in the spinner flask, which allowed a more reliable evaluation of Kolmogorov`s microscales under the conditions 
investigated. Compared to the diameters of the microcarriers, the predicted minimal $(14-19$ $\mu \mathrm{m})$ and mean $(197-268 \mu \mathrm{m})$ Kolmogorov's microscales indicated that some turbulent eddies were in the same order of magnitude. However, the stem cells were only in contact with the critical turbulent eddies $\left(2 / 3 \cdot 1_{\lambda}<d<1_{\lambda}\right)$ for a restricted (short) time and cell death was not detected until day 8 of the cultivations.

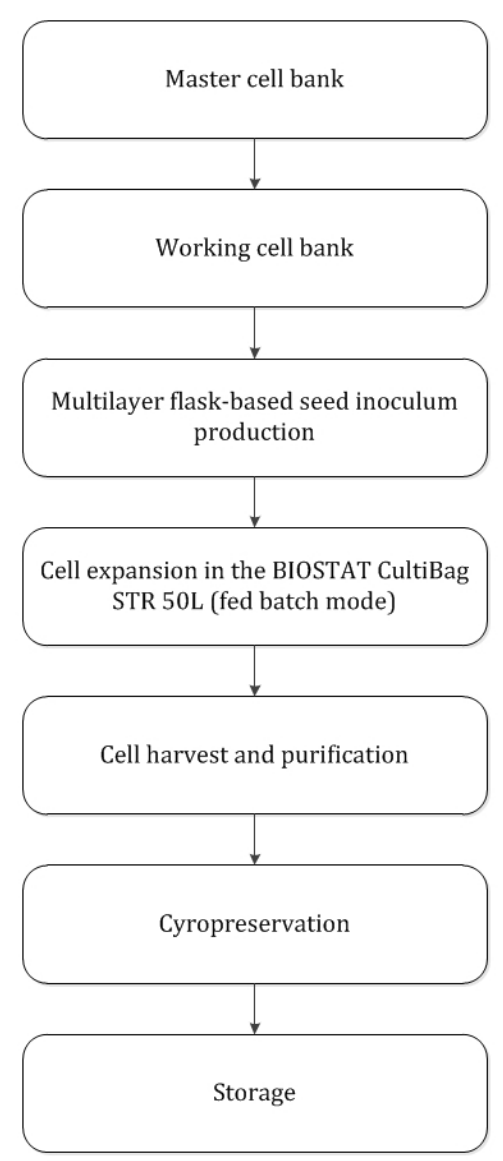

Figure 11. Flow chart showing the main steps of hBM-MSC expansions at pilot scale. hBM-MSCs from the working cell bank (second passage) were used to generate the seed inoculum (2-layer CellSTACKs ${ }^{\circledR}, 1272 \mathrm{~cm}^{2}$ growth surface) within 4 days. After seed inoculum harvest and microcarrier preparation had been carried out according to the manufacturer's recommendations, a 4-hour cell attachment phase was realized by transferring the inoculum to a BIOSTAT ${ }^{\circledR}$ CultiBag RM 20L basic (Sartorius Stedim Biotech) containing the equilibrated gelatin microcarriers. The bag was placed in an incubator and kept stationary to promote attachment of cells. For subsequent stem cell expansion, the microcarrier cell suspension was transferred to the BIOSTAT ${ }^{\circledast}$ CultiBag STR 50L. Pilot runs were started with 35 L working volume at $37^{\circ} \mathrm{C}$, a DO value above $20 \%$, and a maximum air flow rate of $0.03 \mathrm{vvm}$. pH ranged between 7.2 and 7.3, and impeller speeds were between $50 \mathrm{rpm}$ and $66 \mathrm{rpm}$. After cell separation, harvest and purification, the cells were frozen for long-term storage $\left(-196^{\circ} \mathrm{C}\right)$. 
Based on the CFD-predicted engineering parameters and the optimal cultivation conditions derived for the two hMSC types, serum-reduced expansions at $35 \mathrm{~L}$ for the hADSCs and $50 \mathrm{~L}$ for the hBM-MSCs were carried out. Because of the higher clinical relevance of the hBM-MSCs, only one run (fed batch mode with $50 \%$ medium exchange on day 4) was realized for the hADSCs [196], whereas an optimized feeding procedure was developed for the hBM-MSCs. The main process steps of the successful hBM-MSC-based feeding procedure, which is in agreement in the main lines for the $35 \mathrm{~L}$ hADSC production, are shown in Figure 11. A detailed description of the hADS expansion, where the multilayer flask-based seed inoculum production was omitted, can be found in [196].

For both hMSC types comparable cell growth was achieved in both the spinner flask and the BIOSTAT ${ }^{\circledR}$ CultiBag STR 50L runs (Figure $12 \mathrm{~A}$ and B). For the hADSCs, peak viable cell density in the spinner flask was $2.92 \cdot 10^{5}$ cells $\cdot \mathrm{mL}^{-1}$ and $3.0 \cdot 10^{5}$ cells $\cdot \mathrm{mL}^{-1}$ in the BIOSTAT ${ }^{\circledast}$ CultiBag STR 50L. The hADSCs grew with a growth rate of $33.6 \cdot 10^{-3} \mathrm{~h}^{-1}$ in the spinner flask and $30.4 \cdot 10^{-3} \mathrm{~h}^{-1}$ in the BIOSTAT ${ }^{\oplus}$ CultiBag STR 50L, which corresponds to doubling times of 20.6 $\mathrm{h}$ and $22.8 \mathrm{~h}$ respectively [196]. By realizing the optimized feeding approach, the peak viable cell densities of the hBM-MSCs were around 2 to 2.4 times higher $\left(6.8 \cdot 10^{5}\right.$ cells $\cdot \mathrm{mL}^{-1}$ in the spinner flask and $7.2 \cdot 10^{5}$ cells $\cdot \mathrm{mL}^{-1}$ in the BIOSTAT ${ }^{\circledR}$ CultiBag STR 50L) compared to the hADSC expansions. The expansion factor was $39.6 \pm 3.6$ in the spinner flask and $51.5 \pm 4.9$ in the BIOSTAT ${ }^{\circledast}$ CultiBag STR 50 L. These are the highest expansion factors so far reported for serum-reduced hBM-MSC productions [64,191,192]. The hBM-MSCs grew with similar growth rates $(\mu)$ to the hADSCs $\left(34.8 \cdot 10^{-3} \mathrm{~h}^{-1}\right.$ in the spinner flask and $30.4 \cdot 10^{-3} \mathrm{~h}^{-1}$ in the BIOSTAT CultiBag STR 50L), whereby the peak viable cell densities were achieved one day earlier. Cell growth at the end of the cultivations was restricted by the limited microcarrier growth surface.

A)

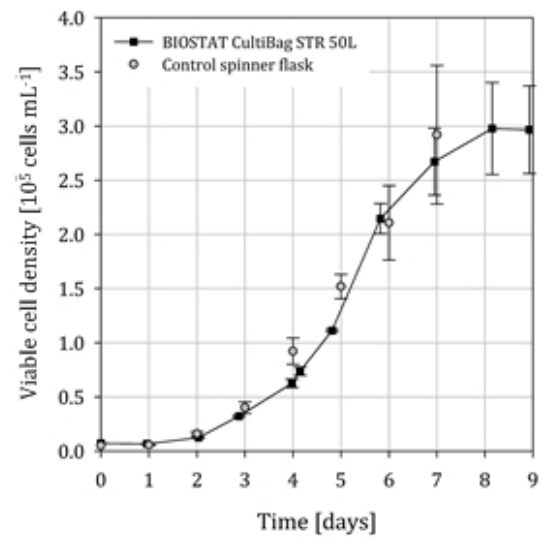

B)

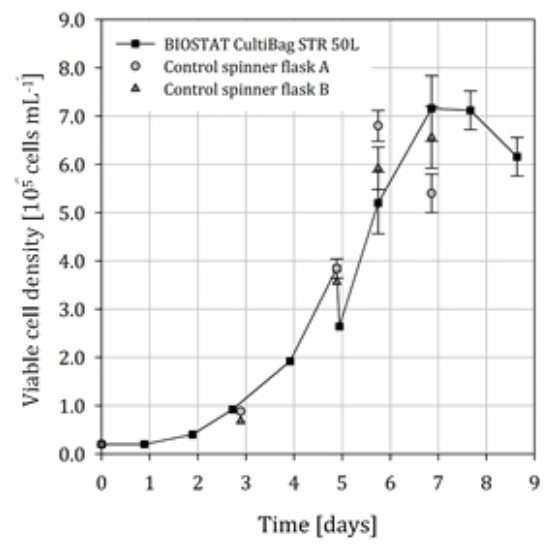

Figure 12. Courses of viable cell densities of hADSCs (A) and hBM-MSCs (B) in the BIOSTAT ${ }^{\circledast}$ CultiBag STR 50L and the control spinner flasks. (A) hADSC cultivation was performed at $35 \mathrm{~L}$ scale (50\% medium exchange on day 4$)$. (B) Optimized hBM-MSC cultivation was performed at $50 \mathrm{~L}$ scale (feed on day 5). 
During all the cultivations the expanded stem cells maintained their stem cell properties and qualities. Figure 13 shows the flow cytometric analysis of hBM-MSC samples. The specific surface markers (CD34- CD45, $\left.{ }^{-} \mathrm{CD} 73^{+}, \mathrm{CD}^{-} 5^{+}, \mathrm{CD} 105^{+}\right)$were determined according to the recommendations of the ISCT [25]. Comparable results were also found for the hADSC cultivations in the BIOSTAT ${ }^{\circledR}$ CultiBag STR 50L [196].

BIOSTAT CultiBag STR 50L
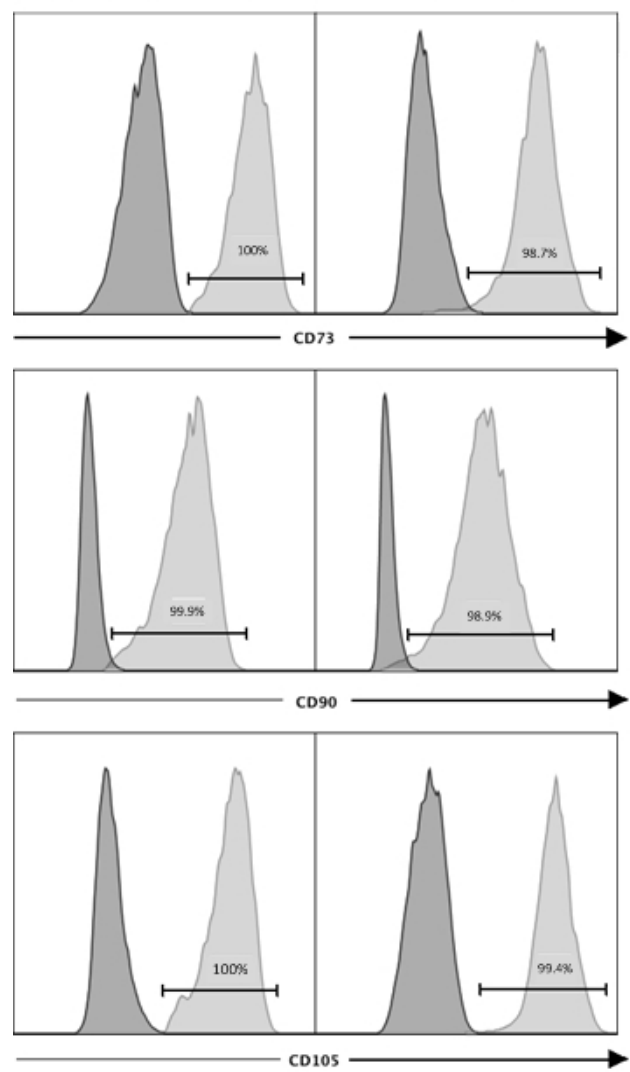

BIOSTAT CultiBag STR 50L Inoculum
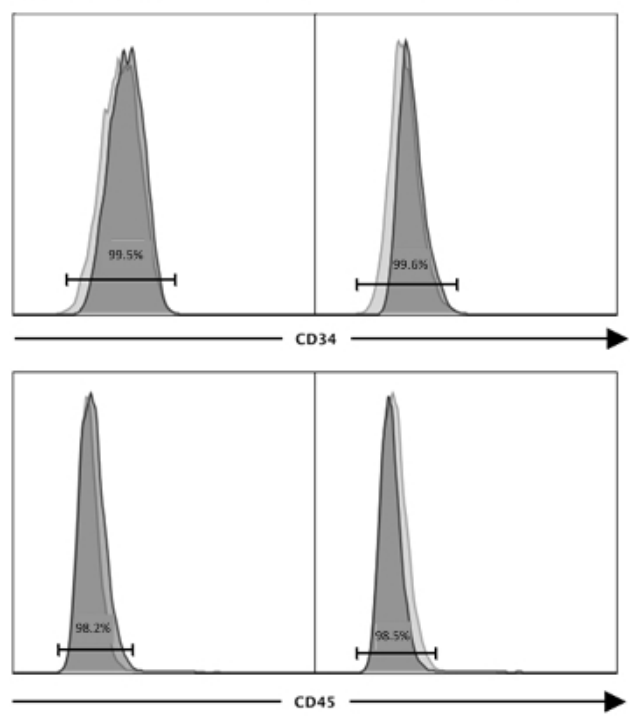

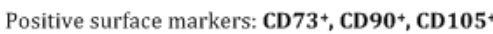

Negative surface markers: CD34; CD45

Figure 13. Flow cytometric analysis (FACS) of specific surface markers performed with hBM-MSC samples before (seed inoculum) and at the end (after harvest) of the expansion procedure. Positive surface markers: $\mathrm{CD}^{+} 3^{+} \mathrm{CD}^{\circ} 0^{+}$, $\mathrm{CD} 105^{+}$. Negative surface markers: CD34- CD45-

\section{Conclusion}

The potential of MSCs is undoubted and explains the increasing clinical interest in high cell yields for therapy approaches. The successful expansion of MSCs to clinically relevant 
numbers and qualities strictly depends on the bioreactor type and its bioengineering parameters, in particular the fluid flow and shear stress. Non-instrumented multilayer vessels normally used for MSC expansion may be advantageously replaced by instrumented dynamic single-use bioreactors. Nowadays, users already have access to stirred, wave-mixed, parallel plate, hollow fiber and fixed bed versions, which confirm the applicability of these bioreactor types for different MSC expansion studies.

For autologous therapies, stirred singles bioreactors operating at benchtop scale and providing yields of $1 \cdot 10^{9} \mathrm{MSC}$ after harvest from microcarriers have proven themselves. Availability of bioreactor CFD models has supported the determination of bioengineering parameters as well as prediction of fluid flow and shear stress. Moreover, knowledge of fluid flow patterns and velocities, local shear stress distributions, turbulent dissipation rates and Kolmogorov`s microscales has contributed to an increase in expansion efficiency and supported avoidance of cell differentiation. Together with microcarrier distribution, these parameters can also be used to rapidly and successfully transfer hADSC-and hBM-MSC-based expansions from mLup to pilot scale. They provide the basis for the production of MSC-derived allogeneic cellular therapeutic products, for which trillion of cells will be required annually.

Stem cell therapeutics are now in transition from development to clinical applications. A large number of stem cell therapeutics are in the clinical pipeline or already in clinical trials [14,31]. This requires clinical-grade bioprocessing and scale-up approaches for expansion of MSCs from human sources. However, the application of MSCs is hampered by a number of facts intrinsic to these cells. As summarized by Wuchter et al. [44], MSCs vary in composition, their cell source (e.g., bone marrow, adipose tissue and cord blood) and the protocols applied for cell isolation and expansion. The available markers are not regarded as sufficient for comparison of data and quality control. Therefore, experimental and clinical data from different laboratories involved in multicenter trials are difficult to compare. Criteria important for quality control include the immunophenotype of the cells, composition of the culture medium and the risk of malignant transformation, as well as the aging and the immunosuppressive potential of the manufactured MSCs [44].

Stem cells could be used in cell therapy either as mass-produced allogeneic cells or autologous cells [31]. In both cases scalable, controlled bioprocessing techniques are required. Establishing these processes is complicated by the fact that guide lines developed for the production of biopharmaceuticals (e.g. monoclonal antibodies) are generally unsuitable for cell therapeutics. Whereas in bioproduction the quality of the product is of major concern and the cells are typically discarded after production, for cell-based therapies the cell-specific properties are essential and require highly specific processes. An overview of the clinical and regulatory pathways for stem cell-based therapies and recent developments is given by $[13,31,44]$.

Future availability of serum-free or even chemically defined culture media and microcarriers allowing simple cell harvest (e.g. after temperature-or $\mathrm{pH}$-shift) and reproducible production will simplify the approval of cell therapeutics. Moreover, it will provide new findings in respect of operational demands and shear stress sensitivity of MSCs. 


\section{Abbreviations}

\begin{tabular}{|c|c|}
\hline $1-\mathrm{D}$ & One-dimensional \\
\hline 2-D & Two-dimensional \\
\hline 3-D & Three-dimensional \\
\hline $\mathrm{CD}$ & Cluster of differentiation (e.g. CD105) \\
\hline CFD & Computational Fluid Dynamics \\
\hline $\mathrm{CHO}$ & Chinese hamster ovary \\
\hline DAPI & 4',6-diamidino-2-phenylindole \\
\hline DMEM & Dulbecco's Modified Eagle's Medium \\
\hline DO & Dissolved oxygen \\
\hline FBS & Fetal bovine serum \\
\hline FCS & Fetal calf serum \\
\hline FGF & Fibroblast growth factor \\
\hline GMP & Good Manufacturing Practice \\
\hline hADSC & Adipose tissue-derived human mesenchymal stem cell \\
\hline hBM-MSC & Bone marrow-derived human mesenchymal stem cell \\
\hline hMSC & Human mesenchymal stem cell \\
\hline hMSC-TERT & Telomerase-immortalized human mesenchymal stem cells \\
\hline ISCT & International Society for Cellular Therapy \\
\hline MSC & Mesenchymal stem cell \\
\hline PIV & Particle Image Velocimetry \\
\hline RANS & Reynolds-averaged Navier-Stokes \\
\hline
\end{tabular}

\section{Symbols}

Latin symbols

\begin{tabular}{lll}
\hline Symbol & Unit & Description \\
\hline $\mathrm{b}$ & $\mathrm{m}$ & Width of flow chamber \\
\hline $\mathrm{d}_{\mathrm{R}}$ & $\mathrm{m}$ & Impeller diameter \\
\hline $\mathrm{D}_{\mathrm{R}}$ & $\mathrm{m}$ & Vessel diameter \\
\hline $\mathrm{F}$ & $\mathrm{m}^{3} \mathrm{~s}^{-1}$ & Flow rate \\
\hline $\mathrm{h}$ & $\mathrm{m}$ & Height of flow chamber \\
\hline
\end{tabular}




\begin{tabular}{|c|c|c|}
\hline Symbol & Unit & Description \\
\hline ISF & $\mathrm{s}^{-1}$ & Integrated shear factor \\
\hline $1_{\mathrm{Kol}}$ & $\mathrm{m}$ & Turbulent Kolmogorov microscale \\
\hline $\mathrm{k}_{\mathrm{L}} \mathrm{a}$ & $\mathrm{h}^{-1}$ & volumetric mass transfer coefficient for oxygen or $\mathrm{CO}_{2}$ \\
\hline $\mathrm{n}_{\mathrm{R}}$ & $\mathrm{s}^{-1}$ & Rotational speed \\
\hline $\mathrm{Ne}$ & - & Newton-Number \\
\hline $\mathrm{N}_{\mathrm{S1}} / \mathrm{N}_{\mathrm{S} 1 \mathrm{U}}$ & $\mathrm{rpm}$ & $\begin{array}{l}\text { Suspension criteria, describing the microcarrier distribution at just fully } \\
\text { suspended conditions }\left(\mathrm{N}_{\mathrm{S} 1}\right) \text { and below }\left(\mathrm{N}_{\mathrm{S} 1 \mathrm{U}}\right)\end{array}$ \\
\hline $\mathrm{P}$ & $\mathrm{W}$ & Power input \\
\hline $\mathrm{P} / \mathrm{V}$ & $\mathrm{W} \mathrm{m}^{-3}$ & Specific volumetric power input \\
\hline $\operatorname{Re}$ & - & Reynolds-Number \\
\hline $\mathrm{u}_{\text {tip }}$ & $\mathrm{m} \mathrm{s}^{-1}$ & Maximum rotating velocity \\
\hline $\mathrm{U}$ & $\mathrm{m} \mathrm{s}^{-1}$ & Flow velocity \\
\hline $\mathrm{V}_{\mathrm{L}}$ & $\mathrm{m}^{3}$ & Liquid volume \\
\hline
\end{tabular}

\section{Greek symbols}

\begin{tabular}{lll}
\hline Symbol & Unit & Description \\
\hline$\alpha_{\mathrm{p}}$ & - & Solid volume fraction \\
\hline$\gamma$ & $\mathrm{s}^{-1}$ & shear rate \\
\hline$\varepsilon$ & $\mathrm{m}^{2} \mathrm{~s}^{-3}$ & Turbulent energy dissipation rate \\
\hline$\eta_{\mathrm{fl}}$ & $\mathrm{Pa} \mathrm{s}$ & Dynamic viscosity \\
\hline$\lambda$ & $\mathrm{nm}$ & Wavelength \\
\hline$\mu$ & $\mathrm{h}^{-1}$ & Specific growth rate \\
\hline$v$ & $\mathrm{~m}^{2} \mathrm{~s}$ & Kinematic viscosity \\
\hline$\varrho_{\mathrm{fl}}$ & $\mathrm{kg} \mathrm{m} \mathrm{m}^{-3}$ & Liquid density \\
\hline$\tau$ & $\mathrm{Pa}$ & Shear stress \\
\hline$\tau_{\mathrm{nt}}$ & $\mathrm{Pa}$ & Local shear stress \\
\hline$\tau_{\mathrm{w}}$ & $\mathrm{Pa}$ & Wall shear stress \\
\hline
\end{tabular}

\section{Acknowledgements}

We want to thank Carmen Schirmaier, Anita Ott and Lidija Lisica from the Group for Biochemical Engineering and Cell Cultivation Techniques Section of the Zurich University of Applied Sciences, and the LIFT team at Lonza Cologne GmbH (Ann Siehoff, Frank Jüngerkes, 
Silke Brill, Agnieszka Safavi-Nab, Sonja Spicker, Barbara Reinisch, Claudia Rosenbaum, Christian van den Bos) for the excellent cooperation and, in particular, the technical support during development of the scale-up approach. Furthermore, we would like to mention that the results presented in Section 5 were generated in a two year research project financially supported by the Lonza and the Commission for Technology and Innovation in Switzerland.

\section{Author details}

Valentin Jossen ${ }^{1}$, Ralf Pörtner ${ }^{2 *}$, Stephan C. Kaiser ${ }^{1}$, Matthias Kraume ${ }^{3}$, Dieter Eibl ${ }^{1}$ and Regine Eibl ${ }^{1}$

*Address all correspondence to: poertner@tuhh.de

1 Zurich University of Applied Sciences, School of Life Sciences and Facility Management, Institute of Biotechnology, Switzerland

2 Hamburg University of Technology (TUHH), Institute of Bioprocess and Biosystems Engineering, Germany

3 Technische Universität Berlin (TU Berlin), Institute of Process Engineering, Germany

\section{References}

[1] Oppermann T, Leber J, Elseberg C, Salzig D, Czermak P. hMSC production in disposable bioreactors in compliance with cGMP guidelines and PAT. Am Pharm Rev. 2014;

[2] Nirmalanandhan VS, Sittampalam GS. Stem cells in drug discovery, tissue engineering, and regenerative medicine: emerging opportunities and challenges. J Biomol Screen. 2009;14(7):755-68.

[3] Kim SU, Lee HJ, Kim YB. Neural stem cell-based treatment for neurodegenerative diseases. Neuropathology. 2013;33(5):491-504.

[4] Mochizuki H, Choong CJ, Yasuda T. The promises of stem cells: stem cell therapy for movement disorders. Park Relat Disord. 2014;20(Suppl 1):128-31.

[5] Calaflore R, Montanucci P, Basta C. Stem cells for pancreatic $\beta$-cell replacement in diabetes mellitus: actual perspectives. Curr Opin Organ Transpl. 2014;19(2):162-8.

[6] Viswanathan C, Sarang S. Status of stem cell based clinical trials in the treatment for diabetes. Curr Diabetes Rev. 2013;9(6):429-36. 
[7] Diekman BO, Gullak F. Stem cell-based therapies for osteoarthritis: challenges and opportunities. Curr Diabetes Rev. 2013;25(1):119-26.

[8] Wei L, Young JZ, Yan J. Potential of Stem Cells for Skin Regeneration Following Burns. Expert Rev Dermatol. 2009;4(2):97-9.

[9] Li SC, Wang LJ, Hong AJ, Chang AC, Loudon WG. Stem cell engineering for treatment of heart diseases: potentials and challenges. Cell Biol Int. 2009;33(3):255-67.

[10] Hall PA, Watt FM. Stem cells: The generation and maintenance of cellular diversity. Development. 1989;106(4):619-33.

[11] Lin H. The tao of stem cells in germline. Annu Rev Genet. 1997;31:455-91.

[12] Giordano A, Galderisi U, Marino IR. From the laboratory bench to the patient's bedside: an update on clinical trials with mesenchymal stem cells. J Cell Physiol. 2007;211:27-35.

[13] Trounson A, Thakar RG, Lomax G, Gibbons D. Clinical trials for stem cell therapies. BMC Med. 2011;9:52.

[14] Ratcliffe E, Glen K, Naing MW, William DJ. Current status and perspectives on stem cell-based therapies undergoing clinical trials for regenerative medicine: case studies. Br Med Bull. 2013;108:73-94.

[15] Inamadar AA, Inamadar AC. Culture conditions for growth of clinical grade human tissue derived mesenchymal stem cells: comparative study between commercial serum-free media and human product suspplemented media. J Regen Med Tissue Eng. 2013;2:10.

[16] Friedenstein AJ, Petrakova K V., Kursolesova AI, Frolova GP. Heterotropic of bone marrow. Analysis of precursor cells for osteogenic and hematopoietic tissues. Transplant. 1968;6:230-47.

[17] Friedenstein AJ, Chailakhjan RK, Lalykina KS. The development of fibroblast colonies in monolayer cultures of guinea-pig bone marrow and speel cells. Cell Tissue Kinet. 1970;3:393-403.

[18] Friedenstein AJ, Gorskaja JF, Kulagina NN. Fibroplast precursors in normal and irradiated mouse hematopoietic organs. Exp Hematol. 1976;4:267-74.

[19] Owen ME, Cave J, Joyner CJ. Clonal analysis in vitro of ostegenic differentiation of marrow CFU-f. J Cell Sci. 1987;Pt5:731-8.

[20] Owen ME, Friedenstein AJ. Stromal stem cells: Marrow derived osteogenic precursors. Giba Found Symp. 1988;136:42.

[21] Caplan AI. Mesenchymal stem cells. J Orthop Res. 1991;9:641-50. 
[22] Pittinger MF, Mackay AM, Beck SC, Jaiswal RK, Douglas R, Mosca JD, et al. Multilineage potential of adult human mesenchymal stem cells. Science (80-). 1999;284:1437.

[23] Goepfert C, Slobodianski A, Schilling AF, Adamietz P, Pörtner R. Cartilage Engineering from Mesenchymal Stem Cells. Adv Biochem Eng Biotechnol. 2010;123:163-200.

[24] Keating A. Mesenchymal stromal cells: New directions. Cell Stem Cell. 2012;10:70916.

[25] Dominici M, Le Blanc K, Mueller I, Slaper-Cortenbach I, Marini F, Krause D, et al. Minimal criteria for defining multipotent mesenchymal stromal cells. The International Society for Cellular Therapy position statement. Cytotherapy. 2006;8(4):315-7.

[26] Zuk PA, Zhu M, Ashija P, Ugarte DA, Huabg JI, Mizuno H, et al. Human adipose tissue is a source of multipotent stem cells. Mol Biol Cell. 2002;13:4279-95.

[27] In't Anker PS, Scherjon SA, van der Keur K, de Groot-Swings GM, Claas FH, Fibbe $\mathrm{WE}$, et al. Isolation of mesenchymal stem cells of fetal or maternal origin from human placenta. Stem Cells. 2004;22(7):1338-45

[28] Frices A, Conget P, Miguell JJ. Mesenchymal progenitor cells in human umbilical cord blood. Br J Haematol. 2000;109:235-42.

[29] Zvaifler NJ, Marinova-Mutafchieva L, Adams G, Edwards CJ, Moss J, Burger JA, et al. Mesenchymal precursor cells in blood of normal individuals. Arthritis Res. 2000;2(6):477-88.

[30] Schallmoser K, Rohde E, Reinisch A, Batmann C, Thaler D, Strunk D. Rapid large scale expansion of functional mesenchymal stem cells from unmanipulated bone marrow without animal serum. Tissue Eng Part C Methods. 2008;14(3):185-96.

[31] Van den Bos C, Keefe R, Schirmaier C, McCaman M. Therapeutic human cells: Manufacture for cell therapy/ regenerative medicine. Adv Biochem Eng Biotechnol. 2014;138:61-97.

[32] Ren G, Chen X, Dong F. Mesenchymal stem cells and translational medicine: Emerging Issues. Stem Cells Transl Med. 2012;1:51-8.

[33] Sharma S, Raju R, Shiu S. Stem cell culture engineering-process scale-up and beyond. Biotechnol. 2011;6(11):1317-29.

[34] Horwitz EM, Prather WR. Cytokines as the major mechanssm of mesenchymal stem cell clinical activity: Expanding the spectrum of cell therapy. Isr Med Assoc J. 2009;11(4):209-11.

[35] Stolzing A, Jones E, McGonagle D. Age-related changes in human bone marrow-derived mesenchymal stem cells: Consequence for cell therapies. Mech Ageing Dev. 2008;129(3):163-73. 
[36] Uccelli A, Moretta L, Pistola V. Mesenchymal stem cells in health and disease. Nat Rev Immunol. 2008;8:726-36.

[37] Chen PM, Yen ML, Liu KJ, Sytwu HK, Yen BL. Immunomodulatory properties of human adult and fetal multipotent mesenchymal stem cells. J Biomed Sci. 2011;18:49.

[38] Caplan AI, Dennis JE. Mesenchymal stem cells as tropic mediators. J Cell Biochem. 2006;98(5):1076-84.

[39] Wang S, Qu X, Zhao RC. Clinical applications of mesenchymal stem cells. J Hematol Oncol. 2012;5:1-9.

[40] Nazarov C, Lo Surdo J, Bauer SR, Wei CH. Assessment of immunosuppressive activity of human mesenchymal stem cells using murine antigen specific CD4 and CD8 T cells in vitro. Stem Cell Res Ther. 2013;4:1-15.

[41] Mannello F, Tonti GA. Concise review: no breakthroughs for human mesenchymal and embryonic stem cell culture: conditioned medium, feeder layer, or feeder-free; medium with fetal calf serum, human serum, or enriched plasma; serum-free, serum replacement nonconditioned medium, or ad hoc formula? All that glitters is not gold! Stem Cells. 2007;25(7):1603-9.

[42] Ankrum J, Karp JM. Mesenchymal stem cell therapy: Two steps forward, one step back. Trends Mol Med. 2010;16:203-9.

[43] Hodges H, Pollock K, Stroemer P, Patel S, Stevanato L, Reuter I, et al. Making stem cell lines suitable for transplantation. Trends Mol Med. 2007;16(2):101-15.

[44] Wuchter P, Bieback K, Schrezenmeier H, Bornhäuser M, Müller LP, Bönig H, et al. Standardization of Good Manufacturing Practice-compliant production of bone marrow-derived human mesenchymal stromal cells for immunotherapeutic applications. Cytotherapy. 2014;

[45] Foley L, Whitaker M. Concise review: cell therapies: the route to widespread adoption. Stem Cells Transl Med. 2012;1(5):438-47.

[46] Shih D, Tzu B, Burnouf T. Preparation, quality criteria, and properties of human blood platelet lysate supplements for ex vivo stem cell expansion. N Biotechnol. 2014;

[47] Sotiropoulou PA, Perez SA, Salagianni M, Baxevanis CN, Papamichail M. Characterization of the optimal culture conditions for clinical scale production of human mesenchymal stem cells. Stem Cells. 2006;24(2):462-71.

[48] De Bruyn C, Najar M, Raicevic G, Meuleman N, Pieters K, Stamatopoulos B, et al. A Rapid, Simple, and Reproducible Method for the Isolation of Mesenchymal Stromal Cells from Wharton's Jelly Without Enzymatic Treatment. Stem Cells Dev. 2010; 
[49] Rhodes NP, Srivastava JK, Smith RF, Longinotti C. Heterogeneity in proliferative potential of ovine mesenchymal stem cell colonies. J Mater Sci Mater Med. 2004;15(4): 397-402.

[50] Kretlow JD, Jin YQ, Wei Z, Wen J, Hong TH, Zhou G, et al. Donor age and cell passage affects differentiation potential of murine bone marrow-derived stem cells. BMC Cell Biol. 2008;9(60).

[51] Colter DC, Class R, Digirolamo CM, Prockop DJ. Rapid expansion of recycling stem cells in cultures of plastic-adherent cells from human bone marrow. Proc Natl Acad Sci U S A. 2000;97:3213-8.

[52] Ikebe C, Suzuki K. Mesenchymal stem cells for regenerative therapy: optimization of cell preparation protocols. Biomed Res Int. 2014; 951512.

[53] Stenderup K, Justesen J, Clausen C, Kassern M. Aging is associated with decreased maximal life span and accelerated senescence of bone marrow stromal cells. Bone. 2003;33(6):919-26.

[54] Pörtner R, Goepfert C, Wiegandt K, Janssen R, Ilinich E, Paetzhold H, et al. Technical Strategies to Improve Tissue Engineering of Cartilage Carrier Constructs-A Case Study. Adv Biochem Eng Biotechnol. 2009;112:145-82.

[55] Fu RH, Wang YC, Liu SP, Huang CM, Kang YH, Tsai CM, et al. Differentiation of stem cells: strategies for modifying surface biomaterials. Cell Transpl. 2011;20(1):3747.

[56] Hudson JE, Mills RJ, Frith JE, Brooke G, Jaramillo-Ferrada P, Wolvetang EJ, et al. A defined medium and substrate for expansion of human mesenchymal stromal cell progenitors that enriches for osteo-and chondrogenic precursors. Stem Cells Dev. 2011;20(1):77-87.

[57] Hwang NS, Varghese S, Li H, Elisseeff J. Regulation of osteogenic and chondrogenic differentiation of mesenchymal stem cells in PEG-ECM hydrogels. Cell Tissue Res. 2012;344(3):499-509.

[58] Wang G, Zheng L, Zhao H, Miao J, Sun C, Ren N, et al. In vitro assessment of the differentiation potential of bone marrow-derived mesenchymal stem cells on genipin-chitosan conjugation scaffold with surface hydroxyapatite nanostructure for bone tissue engineering. Tissue Eng Part A. 2011;17(9-10):1341-9.

[59] He F, Pei M. Extracellular matrix enhances differentiation of adipose stem cells from infrapatellar fat pad toward chondrogenesis. J Tissue Eng Regen Med. 2013;7(1):7384.

[60] Schmitz S. Der Experimentator: Zellkultur. 3rd ed. Spektrum Akad. Verl., Heidelberg; 2011.

[61] Weber C, Freimark D, Pörtner R, Pino-Grace P, Pohl S, Wallrapp C, et al. Expansion of human mesenchymal stem cells in a fixed-bed bioreactorcsystem based on non-po- 
rous glass carrier-Part B: Modeling and scale-up of the system. Int J Artif Organs. 2010;33(11):782-95.

[62] Weber C, Freimark D, Pörtner R, Pino-Grace P, Pohl S, Wallrapp C, et al. Expansion of human mesenchymal stem cells in a fixed-bed bioreactor system based on non-porous glass carrier-Part A: inoculation, cultivation, and cell harvest procedures. Int J Artif Organs. 2010;33(8):512-25.

[63] Szczypka M, Splan D, Woolls H, Brandwein H. Single-Use Bioreactors and Microcarriers. BioProcess Tech. 2014;12(3):54-64.

[64] Rafiq QA, Coopman K, Hewitt CJ. Scale-up of human mesenchymal stem cell culture: current technologies and future challenges. Curr Opin Chem Eng. Elsevier Ltd; 2013 Feb;2(1):8-16.

[65] Rafiq Q a, Brosnan KM, Coopman K, Nienow AW, Hewitt CJ. Culture of human mesenchymal stem cells on microcarriers in a 51 stirred-tank bioreactor. Biotechnol Lett. 2013 Aug;35(8):1233-45.

[66] Sart S, Errachid A, Schneider Y, Agathos SN. Controlled expansion and differentiation of mesenchymal stem cells in microcarrier-based stirred bioreactors. BMC Proc. 2011;5(Suppl 8):55

[67] Chen AKL, Reuveny S, Oh SKW. Application of human mesenchymal and pluripotent stem cell microcarrier cultures in cellular therapy: Achievments and future direction. Biotechnol Adv. 2013;31(7):1032-46.

[68] Elseberg CL, Leber J, Salzig D, Wallrapp C, Kassem M, Moustapha K, et al. Microcarrier-based expansion process for hMSCs with high vitality and undifferentiated characteristics. Int J Artif Organs. 2012;35(2):93-107.

[69] Ferrari C, Balandras F, Guedon E, Olmos E, Chevalot I, Marc A. Limiting cell aggregation during mesenchymal stem cell expansion on microcarriers. Biotechnol Prog. 2012;28:780-7.

[70] Freimark D, Pino-Grace P, Pohl S, Weber C, Wallrapp P, Geigle R, et al. Use of Encapsulated Stem Cells to Overcome the Bottleneck of Cell Avilability for Cell Therapy Approaches. Transfus Med Hemother. 2010;37:66-73.

[71] O'Heireamhoi S, Buckley CT, Jones E, McGonagle D, Mulhall KJ, Kelly DJ. Recapitulating aspects of the oxygen and substrate enviroment of the damaged joint milieu for stem cell-based cartilage tissue engineering. Tissue Eng Part C Methods. 2013;19(2):117-27.

[72] Thanos CG, Emerich DF. On the use of hydrogels in cell encapsulation and tissue engineering system. Recent Pat Drug Deliv Formul. 2008;2(1):19-24. 
[73] Cheung HK, Han TTY, Marecak DM, Watkins JF, Amsden BG, Flynn LE. Composite hydrogel scaffolds incorporating decellularized adipose tissue for soft tissue engineering with adipose-derived stem cells. Biomaterials. 2014;35(6):1914-23.

[74] Kumar D, Gerges I, Taplenizza M, Lenardi C, Forsyth NR, Liu Y. Three-dimensional hypoxic culture of human mesenchymal stem cells encapsulated in a photocurable, biodegradable polymer hydrogel: a potential injectable cellular product for nucleus pulposus regeneration. Acta Biomater. 2014;10(8):3463-74.

[75] Ma J, Yang F, Both SK, Kersten-Niessen M, Bongio M, Pan J, et al. Comparison of cell-loading methods in hydrogel systems. J Biomed mater Res A. 2014;102(4):935-46.

[76] Mohan N, Gupta V, Sridharan B, Sutherland A, Detamore MS. The potential of encapsulating "raw materials" in 3D osteochondral gradient scaffolds. Biotechnol Bioeng. 2014;111(4):829-41.

[77] Naderi-Meshkin H, Andreas K, Matin MM, Sittinger M, Bidkhori HR, Ahmadiankia $\mathrm{N}$, et al. Chitosan-based injectable hydrogel as a promising in situ forming scaffold for cartilage tissue engineering. Cell Biol. 2014;38(1):72-84.

[78] Raghothaman D, Leong MF, Lim TC, Toh JKC, Wan ACA, Yang Z, et al. Engineering cell matrix interactions in assembled polyelectrolyte fiber hydrogels for mesenchymal stem cell chondrogenesis. Biomaterials. 2014;35(9):2607-16.

[79] Tzouanas SN, Ekenseair AK, Kasper FK, Mikos AG. Mesenchymal stem cell and gelatin microparticle encapsulation in thermally and chemically gelling injectable hydrogels for tissue engineering. J Biomed mater Res A. 2014;102(5):122-1230.

[80] Serra M, Brito C, Leite SB, Gorjup E, Von BH, Carondo MJ, et al. Stirred bioreactors for the expansion of adult pancreatic stem cells. Ann Anat. 2009;191:104-15.

[81] Frith JE, Thomson B, Genever PG. Dynamic three-dimensional culture methods enhance mesenchymal stem cell properties and increase therapeutic potential. Tissue Eng Part C Methods. 2010;16:735-49.

[82] Cao C, Zhang H, Gong L, He Y, Zhang N. High glucose conditions suppress the function of bone marrow-derived endothelial progenitor cells via inhibition of the eNOS-caveolin-1 complex. Mol Med Rep. 2012;5(2):341-6.

[83] Dhanasekaran M, Indumathi S, Rajkumar JS, Sudarsanam D. Effect of high glucose on extensive culturing of mesenchymal stem cells derived from subcutaneous fat, omentum fat and bone marrow. Cell Biochem Funct. 2013;31(1):20-9.

[84] Ferrari C, Olmos E, Balandras F, Tran N, Chevalot I, Guedon E, et al. Investigation of growth conditions for the expansion of procine mesenchymal stem cells on microcarriers in stirred cultures. Appl Biochem Biotechnol. 2014;172(2):1004-17. 
[85] Kim SJ, Choi YS, Ko ES, Lim SM, Lee CW, Kim DI. Glucose-stimulated insulin secretion of various mesenchymal stem cells adter insulin-producing cell differentiation. J Biosci Bioeng. 2012;113(6):34-40.

[86] Saki N, Jalalifar MA, Soleimani M, Hajizamani S, Rahim F. Adverse effect of high glucose concentration on stem cell therapy. Int J Hematol Oncol Stem Cell Res. 2013;7(3):34-40.

[87] Sawangmake C, Pavasant P, Chansiripornchai P, Osathanon T. High glucose condition suppresses neurosphere formation by human periodontal ligament-derived mesenchymal stem cells. J Cell Biochem. 2014;115(5):928-39.

[88] Weil BR, Abarbanell AM, Hermann JL, Wang Y, Meldrum DR. High glucose concentration in cell culture medium does not actuely affect human mesenchymal stem cell growth factor production or proliferation. Am J Physiol Regul Integr Comp Physiol. 2009;296(6):1735-43.

[89] Deorosan B, Nauman EA. The role of glucose, serum, and three-dimensional cell culture on the metabolism of bone marrow-derived mesenchymal stem cells. Stem cells Int. 2011;429187.

[90] Li YM, Schilling T, Benisch P, Zeck S, Meissner-Weigl J, Schnider D, et al. Effects of high glucose on mesenchymal stem cell proliferation and differentiation. Biochem Biophys Res Commun. 2007;363(1):209-15.

[91] Stolzing A, Bauer E, Scutt A. Suspension culture of bone-marrow derived mesenchymal stem cells: effects of donor age and glucose level. Stem Cells Dev. 2012;21(14): 2718-23.

[92] Jung MR, Min YL, Pil Y, Han J. High glucose regulates cyclin D1/E of human mesenchymal stem cells through TGF-beta1 expression via Ca2 /PKC/MAPKs and PI3K/Akt/mTOR signal pathways. J Cell Physiol. 2010;224(1):59-70.

[93] Schop D, Janssen FW, van Rijn LD, Fernandes H, Bloem RM, Al. E. Growth, metabolism, and growth inhibitors of mesenchymal stem cells. Tissue Eng Part A. 2009;15(8): 1877-1866.

[94] Lo T, Ho JH, Yang MH, Lee OK. Glucose reduction prevents replicative senescence and increases mitochondrial respiration in human mesenchymal stem cells. Cell Transpl. 2011;20(6):813-25.

[95] Coutu DL, Galipeau J. Roles of FGF signaling in stem cell self-renewal, senescence and aging. Aging (Albany NY). 2011;3(10):920-33.

[96] Clark DA, Coker R. Transforming growth factor-beta (TGF-beta). Int J Biochem Cell Biol. 1998;30(3):293-8.

[97] Yamachika E, Tsujingiwa H, Matsubara M, Hirata Y, Kita K, Takabatake K, et al. Basic fibroblast growth factor supports expansion of mouse compact bone-derived mes- 
enchymal stem cells (MSCs) and regeneration of bine from MSC in vivo. J Mol Histol. 2012;43(2):223-33.

[98] Vallier L, Morgan A, Pedersen R. Activin/Nodal and FGF pathways cooperate to maintain pluripotency of human embryonic stem cells. J Cell Sci. 2005;118(19):4495509.

[99] Jianguo W, Tianhang L, Hong Z, Zhengmao L, Jianwei B, Xuchao X, et al. Optimization of culture conditions for endothelial progenitor cells from porcine bone marrow in vitro. Cell Prolif. 2010;43(4):418-26.

[100] Harmouch C, El-Omar R, Labrude P, Decot V, Menu P, Kerdjoudj H. Influence of serum percentage on the behavior of Wharton's jelly mesenchymal stem cells in culture. Biomed Mater Eng. 2013;23(4):273-80.

[101] Chase LG, Yang S, Zachar V, Yang Z, Lakshimpathy U, Bradford J, et al. Development and characterization of a clinicalls compliant xeno-free culture medium in good manufacturing practice for human multipotent mesenchymal stem cells. Stem Cells Transl Med. 2012;1(10):750-8.

[102] Sotiropoulou PA, Perez SA, Salagianni M, Baxevanis CN, Papamichail M. Cell culture medium composition and translational adult bone marrow-derived stem cell research. Stem Cells. 2006;24(5):1409-10.

[103] Gottipamula S, Sanjay M, Manujunatha S, Chaansa S, Al. E. Isolation, expansion and characterization of bone marrow-derived mesenchymal stromal cells in serum-free conditions. J Tissue Eng Regen Med. 2013;

[104] Jung S, Sen A, Rosenberg L, Behie LA. Human mesenchymal stem cell culture: rapid and efficient isolation and expansion in a defined serum-free medium. J Tissue Eng Regen Med. 2012;6(5):391-403.

[105] Liu Q, Luo Z, He SP, Xinlei X, Al. E. Conditioned serum-free medium from umbilical cord mesenchymal stem cells has anti-photoaging properties. Biotechnol Lett. 2013;35(10):1707-14.

[106] Mark P, Kleinsorge M, Gaebel R, Lux C, Al. E. Human Mesenchymal Stem Cells Display Reduced Expression of CD105 after Culture in Serum-Free Medium. Stem Cells Int. 2013;

[107] Miwa H, Hashimoto Y, Tensho K, Al. E. Xeno-free proliferation of human bone marrow mesenchymal stem cells. Cytotechnology. 2012;64(3):301-8.

[108] Rajaraman G, Whit J, Tan KS, Ulrich D, Al. E. Jerome; Gargett, Caroline E. (2013): Optimization and scale-up culture of human endometrial multipotent mesenchymal stromal cells: potential for clinical application. Tissue Eng Part C Methods. 2013;19(1):80-92. 
[109] Roy S, Arora S, Kumari P, Ta M, Al. E. A simple and serum-free protocol for cryopreservation of human umbilical cord as source of Wharton's jelly mesenchymal stem cells. Cryobiology. 2014;68(3):467-72.

[110] Simöes IN, Boua JS, dos Santos F, Al. E. Human mesenchymal stem cells from the umbilical cord matrix: successful isolation and ex vivo expansion using serum-/xenofree culture media. J Biotechnol. 2013;8(4):448-58.

[111] Swamynathan P, Venugopal P, Kannan S, Al. E. Are serum-free and xeno-free culture conditions ideal for large scale clinical grade expansion of Wharton's jelly derived mesenchymal stem cells? A comparative study. Stem Cell Res Ther. 2014;5(4): 88 .

[112] Wang X, Zheng F, Liu O, Zheng S, Al. E. Epidermal growth factor can optimize a serum-free culture system for bone marrow stem cell proliferation in a miniature pig model. Vitr Cell Dev Biol Anim. 2013;49(10):815-25.

[113] Wu M, Han ZB, Liu JF, Wang Y, Al. E. Serum-free media and the immunoregulatory properties of mesenchymal stem cells in vivo and in vitro. Cell Physiol Biochem. 2014;33(3):569-80.

[114] Dos Santos F, Andrade PZ, Boura JS, Al. E. Ex vivo expansion of human mesenchymal stem cells: a more effective cell proliferation kinetics and metabolism under hypoxia. J Cell Physiol. 2010;223(1):27-35.

[115] Dos Santos F, Campbell A, Fernandes-Platzgummer A, Al. E. Xenogeneic-Free bioreactor system for the clinical-scale expansion of human mesenchymal stem/stromal cells. BiotechnolBioeng. 2014;111(6):1116-27.

[116] Carrancio S, Lopez-Holgado N, Sanchez-Guijo FM, Al. E. Optimization of mesenchymal stem cell expansion procedures by cell separation and culture conditions modification. Exp Hematol. 2008;36(8):1014-21.

[117] Both SK, Van der Muijsenber AJC, van Blitterswijk CA, Boer J, Al. E. A rapid and efficient method for expansion of human mesenchymal stem cells. Tissue Eng. 2007;13(1):3-9.

[118] Bartmann C, Rohde E, Schallmoser K, Al. E. Two steps to functional mesenchymal stromal cells for clinical applications. Transfusion. 2007;47(8):1426-35.

[119] Hewitt CJ, Lee K, Nienow AW, Thomas RJ, Smith M, Thomas CR. Expansion of human mesenchymal stem cells on microcarriers. Biotechnol Lett. 2011 Nov;33(11): 2325-35.

[120] Neuhuber B, Swanger SA, Howard L, Mackay A, Fischer I. Effects of plating density and culture time on bone marrow stromal cell characteristics. Exp Hematol. 2008;36(9):1176-85. 
[121] Stolberg S, McCloskey KE. Can shear stress direct stem cell fate? Biotechnol Prog. 2009;25(1):10-9.

[122] Eibl R, Eibl D, Pörtner R, Catapano G, Czermak P. Cell and Tissue Reaction Engineering. Springer-Verlag Berlin Heidelberg; 2009.

[123] Cherry RS, Papoutsakis TE. Hydrodynamic effects on cells in agitated tissue culture reactors. Bioprocess Eng. 1986;1:29-41.

[124] Chisti Y. Hydrodynamic damage to animal cells. Crit Rev Biotechnol. 2001;21(2):67110.

[125] Croughan MS, Hamel JF, Wang DIC. Hydrodynamic effects on animal cells grown in microcarrier cultures. Biotechnol Bioeng. 1987;29:130-41.

[126] Platas OB, Jandt U, Phan LM, Villanueva ME, Schaletzky M, Rath A, et al. Evaluation of criteria for bioreactor comparison and operation standardisation for mammalian cell culture. Eng Life Sci. 2012;12(5):518-28.

[127] Löffelholz C, Husemann U, Greller G, Meusel W, Kauling J, Ay P, et al. Bioengineering Parameters for Single-Use Bioreactors: Overview and Evaluation of Suitable Methods. Chemie Ing Tech. 2013;85(1-2):40-56.

[128] Zhang H, Wang W, Quan C, Al. E. Engineering considerations for process development in mammalian cell cultivation. Curr Pharm Biotechnol. 2010;11(1):103-12.

[129] Oncul AA, Kalmbach A, Genzel Y, Al. E. Characterization of flow conditions in 2 L and $20 \mathrm{~L}$ wave bioreactors using computational fluid dynamics. Biotechnol Prog. 2010;26(1):101-10.

[130] Singh H, Hutmacher DW. Bioreactor studies and computational fluid dynamics. Adv Biochem Eng Biotechnol. 2009;112:231-49.

[131] Patrachari AR, Podichetty JT, Madihally S V. Application of computational fluid dynamics in tissue engineering. J Biosci Bioeng. 2012;114(2):123-32.

[132] Liovic P, Šutalo ID, Stewart R, Glattauer V, Meagher L. Fluid flow and stresses on microcarriers in spinner flask bioreactors. Ninth Int Conf CFD Miner Process Ind. 2012;1-6.

[133] Song K, Wang H, Zhang B, Al. E. Numerical simulation of fluid field and in vitro three-dimensional fabrication of tissue-engineered bones in a rotating bioreactor and in vivo implantation for repairing segmental bone defects. Cell Stress Chaperones. 2013;18(2):193-201.

[134] Burdick JA, Vunjak-Novakovic G. Engineered microenvironments for controlled stem cell differentiation. Tissue Eng Part A. 2009;15(2):205-19. 
[135] Anderson EJ, Kaliyamoorthy S, Iwan J, Alexander D, Knothe T, Melissa L. Nano-microscale models of periosteocytic flow show differences in stresses imparted to cell body and processes. Ann Biomed Eng. 2005;33(1):52-62.

[136] Zhang H, Dau S, Bi J, Liu KK. Biomimetic three-dimensional microenvironment for controlling stem cell fate. Interface Focus. 2011;1(5):792-803.

[137] Higuera GA, van Boxtel A, van Blitterswijk CA, Moroni L. The physics of tissue formation with mesenchymal stem cells. Trends in Biotechnol. 2012;30(11):583-90.

[138] Yeatts AB, Chouquette DT, Fisher JP. Bioreactors to influence stem cell fate: augmentation of mesenchymal stem cell signaling pathways via dynamic culture systems. BiochimBiophysActa. 2013;1830(2):2470-80.

[139] Adamol L, Garcia-Cardena G. Directed stem cell differentiation by fluid mechanical forces. Antioxid Redox Signal. 2011;15:1463-73.

[140] Chang H, Wang Y. Cell Responses to Surface and Architecture of Tissue Engineering Scaffolds. Regenerative Medicine and Tissue Engineering-Cells and Biomaterials. InTech; 2011.

[141] Prockop DJ, Brenner M, Fibbe WE, Horwitz E, Le BK, Phinney DG, et al. Defining the risks of mesenchymal stromal cell therapy. Cytotherapy. 2010;12:576-8.

[142] Prockop DJ, Oh JY. Medical therapies with adult stem/progenitor cells (MSCs): a backward journey from dramatic results in vivo to the cellular and molecular explanations. J Cell Biochem. 2012;113:1460-9.

[143] Luo W, Xiong W, Zhou J, Fang Z, Chen W, Fan Y, et al. Laminar shear stress delivers cell cycle arrest and anti-apoptosis to mesenchymal stem cells. Acta Biochim Biophys Sin. 2011;43:210-6.

[144] Maul TM, Chew DW, Nieponice A, Vorp DA. Mechanical stimuli differentially control stem cell behavior: morphology, proliferation, and differentiation. Biochem Model Mechanobiol. 2011;10:939-53.

[145] Yi W, Sun Y, Wei X, Gu C, Dong X, Kang X, et al. Proteomic profiling of human bone marrow mesenchymal stem cells under shear stress. Mol Cell Biochem. 2010;341:916.

[146] Zhang H, Kay A, Forsyth NR, Liu KK, El Haj AJ. Gene expression of single human mesenchymal stem cell in response to fluid shear. J Tissue Eng. 2012;3(1).

[147] Zheng W, Xie Y, Zhang W, Wang D, Ma W, Wang Z, et al. Fluid flow stress induced contraction and re-spread of mesenchymal stem cells: a microfluidic study. Integr Biol. 2012;4(9):1102-11.

[148] Barron MJ, Tsai CJ, Donahue S, Al. E. Mechanical stimulation mediates gene expression in MC3T3 osteoblastic cells differently in 2D and 3D environments. J Biomech Eng. 2010;132(4). 
[149] Kim J, Ma T. Bioreactor strategy in bone tissue engineering: pre-culture and osteogenic differentiation under two flow configurations. Tissue Eng Part A. 2012;18(21-22):2354-64.

[150] Li D, Tang T, Lu J, Al. E. Effects of flow shear stress and mass transport on the construction of a large-scale tissue-engineered bone in a perfusion bioreactor. Tissue Eng Part A. 2009;15(10):2773-83.

[151] Liu YB, Chen J, Tang Z, Al. E. Different effects of intermittent and continuous fluid shear stresses on osteogenic differentiation of human mesenchymal stem cells. Biomech Model Mechanobiol. 2012;11(3-4):391-401.

[152] Yourek G, McCormick SM, Mao JJ, Reilly GC. Shear stress induces osteogenic differentiation of human mesenchymal stem cells. Regen Med. 2010;5(5):713-24.

[153] Yu X, Botchwey EA, Levine EM, Al. E. Bioreactor-based bone tissue engineering: the influence of dynamic flow on osteoblast phenotypic expression and matrix mineralization. Proc Natl Acad Sci. 2004;101(31):11203-8.

[154] Grellier M, Bareille R, Bourget C, Al. E. Responsiveness of human bone marrow stromal cells to shear stress. J Tissue Eng Regen Med. 2009;3(4):302-9.

[155] Da Silva AML, Marins A, Costa-Pinto AR, Al. E. Chondrogenic differentiation of human bone marrow mesenchymal stem cells in chitosan-based scaffolds using a flowperfusion bioreactor. J Tissue Eng Regen Med. 2011;5(9):722-32.

[156] Wescoe KE, Schugar RC, Chu CR, Al. E. The role of the biochemical and biophysical environment in chondrogenic stem cell differentiation assays and cartilage tissue engineering. Cell Biochem Biophys. 2008;52(2):85-102.

[157] Pörtner R, Hsu HH, Goepfert C. Bioreaktoren für Knochen Tissue Engineering. Osteologie. 2013;22(3):188-95.

[158] Weinbaum S, Cowin SC, Zeng Y. A model for the excitation of osteocytes by mechanical loading induced bone fluid shear stresses. J Biomech. 1994;27:339-60.

[159] Holtorf HL, Sheffield TL, Ambrose CG, Al. E. Flow perfusion culture of marrow stromal cells seeded on porous biphasic calcium phosphate ceramics. Ann Biomed Eng. 2005;33(9):1238-48.

[160] Bjerre L, Bünger CE, Kassern M, Al. E. Flow perfusion culture of human mesenchymal stem cells on silicate-substituted tricalcium phosphate scaffolds. Biomaterials. 2008;29:2616-27.

[161] Datta N, Pham QP, Sharma U, Al. E. In vitro generated extracellular matrix and fluid shear stress synergistically enhance 3D osteoblastic differentiation. PNAS. 2006;103(8):2488-93. 
[162] Zhao F, Chella R, Ma T. Effects of shear stress on 3-D human mesenchymal stem cell construct development in a perfusion bioreactor system: Experiments and hydrodynamic modeling. Biotechnol Bioeng. 2007;96:584-95.

[163] Wang LH, Hu YY, Wang Z, Al. E. Flow perfusion of human fetal bone cells in large beta-tricalcium phosphate scaffold with controlled architecture. J Biomed Mat Res Part A. 2008;

[164] Maes F, van Ransbeeck P, van Oosterwyck H, Al. E. Modeling fluid flow through irregular scaffolds for perfusion bioreactors. BiotechnolBioeng. 2009;103(3):621-30.

[165] Chen Y, Zhou S, Cadman J, Al. E. Design of cellular porous biomaterials for wall shear stress criterion. Biotechnol Bioeng. 2010;107(4):737-46.

[166] Xu S, Pigan D, Youthuan X, Al. E. Cell distribution in a scaffold with random architectures under the influence of fluid dynamics. J Biomater Appl. 2008;23(3):229-45.

[167] Bjerre L, Bünger C, Baatrup A, Al. E. Flow perfusion culture of human mesenchymal stem cells on coralline hydroxyapatite scaffolds with various pore sizes. J Biomed mater Res A. 2011;97(3):251-63.

[168] Nienow AW, Qasim A, Rafiq K, Al. E. A Potentially Scalable Method for the Harvesting of hMSCs from Microcarriers. Eng J. 2014;

[169] Cormier JT, Zur Nieden NI, Rancourt DE, Kallos MS. Expansion of undifferentiated murine embryonic stem cells as aggregates in suspension culture bioreactors. Tissue Eng. 2006;12(11):3233-45.

[170] Keller KC, Rodrigues B, Zur Nieden NI. Suspension culture of pluripotent stem cells: effect of shear on stem cell fate. Crit Rev Eukaryot Gene Expr. 2014;24(1):1-13.

[171] Kresnowati MTAP, Forde G, Chen XD. Model-based analysis and optimization of bioreactor for hematopoietic stem cell cultivation. Bioprocess Biosyst Eng. 2011;34(1): 81-93.

[172] Sen A, Kallos MS, Behie LA. Expansion of mammalian neural stem cells in bioreactors: effect of power input and medium viscosity. Brain Res Dev Brain Res [Internet]. 2002 Mar 31;134(1-2):103-13. Available from: http://www.ncbi.nlm.nih.gov/pubmed/ 11947941

[173] Blüml G. Microcarrier cell culture technology. In: Pörtner R, editor. Animal cell biotechnology. 2007. p. 149-78.

[174] Rowley J, Abraham E, Campbell A, Brandwein H, Oh S. Meeting lot-size challenges of manufacturing adherent cells for therapy. BioProcess Int. 2012;10:16-22.

[175] Aunins JG, Bader B, Caola A. Fluid mechanics, cell distribution and environment in CellCube Bioreactors. Biotechnol Prog. 2003;19:2-8. 
[176] Goltry KL, Hampson BS, Venturi NA, Batel RL. Adult stem cell therapies for tissue regeneration: Ex vivo expansion in an automated system. In: Yanhong S, Clegg DO, editors. Stem Cell research and Therapeutics. Springer; 2008. p. 251-74.

[177] Reichardt A, Polchow B, Shakibaei M, Henrich W, Hetzer R, Lueders C. Large scale expansion of human umbilical cord cells in a rotating bed system for cardiovascular tissue engineering applications. Open Biomed Eng J. 2014;7:50-61.

[178] Chen HC, Hu YC. Bioreactors for tissue engineering. Biotechnol Lett. 2006;28:141523.

[179] Eibl R, Kaiser S, Lombriser R, Eibl D. Disposable bioreactors: the current state-of-the art and recommended applications in biotechnology. Appl Microbiol Biotechnol. 2010;86:41-9.

[180] Yan ST, Liu X. Cell culture processes for biologics manufacturing: recent developments and trends. Pharm Bioprocess. 2013;1:133-6.

[181] Shukla AA, Gottschalk U. Single-use disposable technologies for biopharmaceutical manufacturing. Trends in Biotechnol. 2013;31:147-54.

[182] Kaiser SC, Kraume M, Eibl D, Eibl R. Single-use bioreactors for animal and human cells. In: Rubeai M, editor. Cell engineering vol 9. Springer; 2014. p. (in press).

[183] Eibl R, Löffelholz C, Eibl D. Single-use bioreactors: an Overview. In: Eibl R, Eibl D, editors. Single Use Technology in Biopharmaceutical Manufacture. Wiley VCH; 2011. p. 33-51.

[184] Horvath B, Tsang VL, Lin W, Dai XP, Kunas K, Frank GA. A generic growth test method for improving quality control of disposables in industrial cell culture. BioPharm Int. 2013;23:34-41.

[185] Wood J, Mahaian E, Shiratori M. Strategy for selecting disposable bags for cell culture media applications based on root-cause investigations. Biotechnol Prog. 2013;

[186] Hammond N, Nunn H, Rogers G, Lee H, Marghitou AL, Nashed-Samuel Y, et al. Identification of a leachable compound detrimental to cell growth in single-use bioprocess containers. PDA J Pharm Sci Technol. 2014;67:123-34.

[187] Steiger N, Eibl R. Interlaboratory test for detection of cytotoxic leachables arising from single-use bags. Chemie Ing Tech. 2013;85:26-8.

[188] Hammond M, Marghitoiu L, Lee H, Perez L, Rogers G, Nashed-Samuel Y. A cytotoxic leachable compound from single-use bioprocess equipment that causes poor cell growth performance. Biotechnol Prog. 2014;30(2):332-7.

[189] Ott A. Kultivierung und Zellrückgewinnung von humanen mesenchymalen Stammzellen in einem modifizierten Bioreaktor. Zurich University of Applied Science, Switzerland, Master's Thesis; 2014. 
[190] Kaiser SC, Eibl R, Eibl D. Engineering characteristics of a single-use stirred bioreactor at bench-scale: The Mobius CellReady 3L bioreactor as a case study. Eng Life Sci. 2011 Aug 28;11(4):359-68.

[191] Cierpka K, Elseberg CL, Niss K, Kassem M, Salzig D, Czermak P. hMSC Production in Disposable Bioreactors with Regards to GMP and PAT. Chemie Ing Tech. 2013 Feb 19;85(1-2):67-75.

[192] Jing D, Sunil N, Punreddy S, Aysola M. Growth Kinetics of Human Mesenchymal Stem Cells in a 3-L Single-Use, Stirred-Tank Bioreactor. BioPharm Int. 2013;26:28-38.

[193] Stadler M. Stammzellkultivierung auf Microcarriern und Zellernte. Zurich University of Applied Sciences, Switzerland, Bachelor thesis; 2013.

[194] Kaiser S, Löffelholz C, Werner S, Eibl D. CFD for characterizing standard and singleuse stirred cell culture bioreactors. Computational Fluid Dynamics. InTech; 2011. DOI:10.5572/23496

[195] Löffelholz C. CFD als Instrument zur bioverfahrenstechnischen Charakterisierung von single-use Bioreaktoren und zum Scale-up für Prozesse zur Etablierung und Produktion von Biotherapeutika. Brandenburg University of Technology, Germany, $\mathrm{PhD}$ thesis; 2013.

[196] Schirmaier C, Jossen V, Kaiser SC, Jüngerkes F, Brill S, Safavi-Nab A, et al. Scale-up of adipose tissue-derived mesenchymal stem cell production in stirred single-use bioreactors under low-serum conditions. Eng Life Sci. 2014;14(3):292-303.

[197] Jossen V, Kaiser SC, Schirmaier C, Herrmann J, Tappe A, Eibl D, et al. Modification and qualification of a stirred single-use bioreactor for the improved expansion of human mesenchymal stem cells at benchtop scale. Pharm Bioprocess. 2014;2(4):311-322.

[198] Eibl R, Werner S, Eibl D. Bag bioreactor based on wave-induced motion: characteristics and applications. Disposable bioreactors. Springer-Verlag Berlin Heidelberg; 2010 .

[199] Werner S, Eibl R, Lettenbauer C, Röll M, Eibl D, Jesus M. Innovative, non-stirred bioreactors in scales from milliliters up to 1000 liters for suspension cultures of cells using disposable bags and containers. A Swiss contribution. Chimia (Aarau). 2010;64:819-23.

[200] Hundt B, Best C, Schlawin N, Kassner H, Genzel Y, Reichel U. Establishment of a mink eneritis vaccine production process in stirred-tank reactor and Wave Bioreactor microcarrier culture in 1-10 L scale. Vaccine. 2007;25:3987-95.

[201] Genzel Y, Behrendt I, König S, Sann H, Reichl U. Metabolism of MDCK cells during cell growth and influenza virus production in large-scale microcarrier culture. Vaccine. 2004;22:2202-8. 
[202] Genzel Y, Dietzsch C, Rapp E, Schwarzer J, Reichl U. MDCK and Vero cells for influenza virus vaccine production: a one-to-one comparison up to lab-scale bioreactor cultivation. Appl Microbiol Biotechnol. 2010;88:461-75.

[203] Slivac I, Srcek VG, Radoservic K, Kmetic I, Kniewald Z. Aujeszky's disease virus production in disposable bioreactor. J Biosci. 2006;31(3):363-8.

[204] Hami LS, Green C, Leshinsky N, Markham E, Miller K, Craig S. GMP production and testing of xcellerated $\mathrm{t}$ cells for the treatment of patients with cell. Cytotherapy. $2004 ; 6: 554-62$.

[205] Akerström. Expansion of adherent cells for cell therapy. Uppsala University, Sweden; 2009.

[206] Timmins NE, Kiel M, Günther M, Heazlewood C, Doran MR, Brooke G, et al. Closed system isolation and scalable expansion of human placental mesenchymal stem cells. Biotechnol Bioeng. 2012;109(7):1817-26.

[207] Shyu Y, Stratheam KE, Eglen RM. Large-scale expansion of stem cells for therapy and screening. Drug Discov World Winter. 35-9.

[208] Peng CA, Palsson BO. Stem cell replication and differentiation in tissue engineering bioreactors strongly influenced by bioreactor geometry. Biotechnol Bioeng. 1996;50:479-92.

[209] Nielsen LK. Bioreactors for Hematopoietic Cell Culture. Annu Rev Biomed Eng. 1999;1:129-52.

[210] Whitford WG, Hardy JC, Cadwell JJS. Single-Use, Continous Processing of Primary Stem Cells. Cell Ther Process. 2014;12(3):27-33.

[211] Knazek RA, Wu Y-W, Aebersold PM, Rosenberg SA. Culture of himan tumor inflitrating lymphocytes in hollow fibre bioreactors. Immunol Methods. 1990;127(1):2937.

[212] Malone CC, Scholtz PM, Mackintosh AD, Beutel LD, Heinemann FS, Dillman RO. Characterization of human tumor-infiltrating lymphocytes expanded in hollow-fiber bioreactors for immunotherapy of cancer. Radiopharm. 2001;16:381-90.

[213] De Bartolo L, Piscioneri A, Cotroneo G, Salerno S, Tasselli F, Campana C, et al. Human lymphocyte peek-wc hollow fiber membrane bioreactor. J Biotechnol. 2007;132(1):65-74.

[214] Pan D, Whitley CB. Closed hollow-fiber bioreactor: a new approach to retroviral vector production. Gene Med. 1999;1:433-40.

[215] Gardner TA, Ko SC, Yang L, Cadwell J j. Serum-free recombinant production of adenovirus using a hollow fiber capillary system. Biotechniques. 2001;30:422-7. 
[216] Gramer MJ, Maas J. Optimal NS0 cell growth in a hollow fiber bioreactor requires increased serum concentration or a cholesterol supplement on the cell side of the fiber. Biotechnol Prog. 2003;19:1762-6.

[217] Kalbfuss B, Grenzel Y, Wolff M, Zimmermann A, Morenweiser R, Reichl U. Harvesting and concentration of human influenza A virus produced in serum-free mammalian cell culture for the production of vaccines. Biotechnol Bioeng. 2007;97(1):73-85.

[218] Kuhn J, Mölle K, Brinkmann T, Götting C, Kleesiek K. High-density tissue-like cultivation of JAR chorocarcinoma cells for the in vitro production of human xylosyltransferase. J Biotechnol. 2003;103:191-6.

[219] Hopkinson J. Hollow fibre cell culture systems for economical cell-product manufacturing. Biotechnology. 1985;3:225-30.

[220] Gorter A, van de Gried R, van Eendenburg JD, Haasnot WH, Fleuren G. Production of bispecific monoclonal antibodies in a hollow-fibre bioreactor. J Immunol Methods. 1993;161:145-50.

[221] Marx U. Membrane-based cell culture technologies: A scientifically, economically satisfactory alternative malignant ascites production for monoclonal antibodies. Res Immunol. 1998;6:557-9.

[222] Abu-Abs SF, Seth G, Narayana RA, Groehler K, Lai P, Anderson ML, et al. Characterization of a hollow fiber bioartificial liver device. Atif Organs. 2005;29(5):419-22.

[223] Curcio E, De Bartolo L, Barbieri G, Rende M, Giorno L, Morelli S. Diffusive and convective transport through hollow fiber membranes for liver cell culture. J Biotechnol. 2005;117:309-21.

[224] Men Q, Zhang G, Wu D. Hepatocyte culture in bioartifical livers with different membrane characteristics. Biotechnol Lett. 2004;26:1407-12.

[225] Nordon RE, Schindhelm K. Design of hollow fiber modules for uniform shear elution affinity cell separation. Artif Organs. 1997;21(2):107-15.

[226] Godara P, McFarland CD, Nordon RE. Design of bioreactors for mesenchymal stem cell tissue engineering. J Chem Technol. 2008;83(4):408-20

[227] Hambor J. Bioreactor design and bioprocess controls for industrialized cell processing. BioProcess Int. 2012;10(6):22-33.

[228] Rojewski MT, Fekete N, Baila S, Nguyen K, Fürst D, Antwiler D, et al. GMP-compliant isolation and expansion of bone marrow-derived MSCs in the closed, automated device Quantum Cell Expansion System. Cell Transplant. 2013;22(11):1981-2000.

[229] Jones M, Varella-Garcia M, Skokan M, Bryce S, Schowinsky J, Peters R, et al. Genetic stability of bone marrow-derived human mesenchymal stromal cells in the Quantum System. Cytotherapy. 2013;15(11):1323-39. 
[230] Hanley PJ, Mci Z, Durette AG, Cabreira-Harrison MD, Klis M, Li W, et al. Efficient manufacturing of therapeutic mesenchymal stromal cells with the use of the Quantum Cell Expansion System. Cytotherapy. 2014;16(8):1048-58.

[231] Wang TY, Brennan JK, Wu JH. Multilineal hematopoiesis in a three-dimensional murine long-term bone marrow culture. Exp Hematol. 1995;23(1):26-32.

[232] Warnrock JN, Bratch K, Al-Rubeai M. Packed bed bioreactors. In: Chaudhuri J, AlRubeai M, editors. Bioreactors for tissue engineering. Springer; 2005. p. 87-113.

[233] Mantalaris A, Keng P, Bourne P, Cheng A, Wu J. Engineering a human bone marrow model: a case study on ex vivo erythropoiesis. Biotechnol Prog. 1998;14(1):126-33.

[234] Meissner P, Schröder B, Herfurth C, Biselli M. Development of a fixed bed bioreactor for the expansion of human hematopoietic progenitor cells. Cytotechnology. 1999 Jul; 30(1-3):227-34.

[235] Jelinek N, Schmidt S, Hilbert U, Thoma S, Biselli M, Wandrey C. Novel bioreactors for the ex vivo cultivation of hematopoietic cells. Eng Life Sci. 2002;7(1):15-8.

[236] Meuwly F, Loviat F, Ruffieux PA, Bernard AR, Kadouri A, von Stocker U. Oxygen supply for $\mathrm{CHO}$ cells immobilized on a packed-bed of Fibra-Cell disks. Biotechnol Bioeng. 2006;93:791-800.

[237] Meuwly F, Ruffieux PA, Kadouri A, von Stocker U. Packed-bed bioreactors for mammalian cell culture: bioprocess and biomedical applications. Biotechnol Adv. 2007;25:45-56.

[238] Lennaertz A, Knowles S, Drugmand JC, Castillo J. Viral vector production in the Integrity iCELL is single-use fixed-bed bioreactor, from bench-scale to industrial scale. BMC Proc. 2013;7:59.

[239] Weber C, Pohl S, Pörtner R, Wallrapp C, Kassern M, Geigle P, et al. Cultivation and differentiation of encapsulated hMSC-TERT in a disposable small-scale syringe-like fixed bed reactor. Open Biomed Eng J. 2007;1:64-70.

[240] Kunas KT, Papoutsakis TE. Damage mechanisms of suspended animal cells in agitated bioreactors with and without bubble entrainment. Biotechnol Bioeng. 1990;36(5): 476-83.

[241] Shiragami N. Effect of shear rate on hybridoma cell metabilism. Bioprocess Eng. 1997;16(6):345-7.

[242] Nienow AW. Reactor engineering in large scale animal cell culture. Cytotechnology. 2006;50(1):9-33.

[243] Huang Y, Xiaoling L, Bai K, Gong X, Fan Y. Effect of Fluid Shear Stress on Cardiomyogenic Differentiation of Rat Bone Marrow Mesenchymal Stem Cells. Arch Med Res. 2010;41:497-505. 
[244] Thomassen YE, van der Well JE, van Eikenhorst G, van der Pol LA, Bakker WAM. Transfer of an adherent Vero cell culture method between two different rocking motion type bioreactors with respect to cell growth and metabolic rates. Process Biochem. 2012;47(2):288-96.

[245] Nienow AW. On impeller circulaton and mixing evectiveness in the turbulent flow regime. Chem Eng Sci. 1997;52(15):2557-65.

[246] Chaubard JF, Dessoy S, Ghislain Y, Gerkens P, Barhier B, Battisti R, et al. Disposable bioreactors for viral vaccine production: challenges and opportunities. BioPharm Int Suppl. 2010; http://www.biopharminternational.com/biopharm/Disposables/Disposable-Bioreactor-for-Viral-Vaccine-Production/ArticleStandard/Article/detail/695153.

[247] Junker BH. Scale-up methologies for Escherichia coli and yeast fermentation processes. J Biosci Bioeng. 2004;97(6):347-64.

[248] Xing Z, Kenty BM, Li ZJ, Lee SS. Scale-up analysis for a CHO cell culture process in large-scale bioreactors. Biotechnol Bioeng. 2009;103(4):733-46.

[249] Löffelholz C, Kaiser SC, Kraume M, Eibl R, Eibl D. Dynamic Single-Use Bioreactors Used in Modern Liter-and m3-Scale Biotechnological Processes: Engineering Characteristics and Scaling UP. AdvBiochemEngBiotechnol. 2014;138:1-41

[250] Zwietering T. Suspending of solid particles in liquid by agitators. Chem Eng Sci. 1958;8(3-4):244-53.

[251] Liepe F, Sperling R, Solomon J. Rührwerke: Theoretische Grundlagen, Auslegung und Bewertung. Eigenverlag Fachhochschule Köthen; 1998.

[252] Ibrahim S, Nienow AW. Suspension of Microcarriers for Cell Culture with Axial Flow Impellers. Chem Eng Res Des. 2004;82(9):1082-8.

[253] Van Heimburg D, Hemmrich K, Zachariah S, Staiger H, Pallua N. Oxygen consumption in undifferentiated versus differentiated adipogenic mesenchymal precursor cells. Respir Physiol Neurobiol. 2005;146(3):107-16.

[254] Zhao F, Pathi P, Garyson W, Xing Q, Locke BR, Ma T. Effects of oxygen transport on 3-d human mesenchymal stem cell metabolic activity in perfusion and static cultures: experiments and mathematical model. Biotechnol Prog. 2005;21(4):1269-80.

[255] Kaiser SC, Jossen V, Schirmaier C, Eibl D, Brill S, van den Bos C, et al. Fluid Flow and Cell Proliferation of Mesenchymal Adipose-Derived Stem Cells in Small-Scale, Stirred, Single-Use Bioreactors. Chemie Ing Tech. 2013;85(1-2):95-102.

[256] Jung S, Panchalingam KM, Rosenberg L, Behie LA. Ex vivo expansion of human mesenchymal stem cells in defined serum-free media. Stem Cells Int. 2012;2012:21 pages.

[257] Ponnuru K, Wu J, Ashok P, Tzanakakis E, Furlani EP. Analysis of Stem Cell Culture Performance in a Microcarrier Bioreactor System. Proc Int NSTI Nanotech Conf. 2014;2:132-5. 
[258] Löffelholz C, Kaiser SC, Kraume M, Eibl R, Eibl D, Löffelholz C, et al. Dynamic Single-Use Bioreactors Used in Modern Liter-and m 3-Scale Biotechnological Processes: Engineering Characteristics and Scaling Up. Biochem Eng Biotechnol. 2014;138:1-41. 